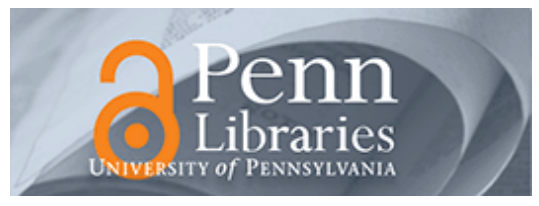

University of Pennsylvania ScholarlyCommons

Finance Papers

Wharton Faculty Research

2000

\title{
Is the Abnormal Return Following Equity Issuances Anomalous?
}

Alon Brav

Christopher C. Geczy

University of Pennsylvania

Paul A. Gompers

Follow this and additional works at: https://repository.upenn.edu/fnce_papers

Part of the Finance Commons, and the Finance and Financial Management Commons

\section{Recommended Citation}

Brav, A., Geczy, C. C., \& Gompers, P. A. (2000). Is the Abnormal Return Following Equity Issuances Anomalous?. Journal of Financial Economics, 56 (2), 209-249. http://dx.doi.org/10.1016/ S0304-405X(00)00040-4

This paper is posted at ScholarlyCommons. https://repository.upenn.edu/fnce_papers/361

For more information, please contact repository@pobox.upenn.edu. 


\title{
Is the Abnormal Return Following Equity Issuances Anomalous?
}

\author{
Abstract \\ We examine whether a distinct equity issuer underperformance anomaly exists. In a sample of initial \\ public offering (IPO) and seasoned equity offering (SEO) firms from 1975 to 1992, we find that \\ underperformance is concentrated primarily in small issuing firms with low book-to-market ratios. SEO \\ firms, that underperform these standard benchmarks have time series returns that covary with factor \\ returns constructed from nonissuing firms. We conclude that the stock returns following equity issues \\ reflect a more pervasive return pattern in the broader set of publicly traded companies. \\ Disciplines \\ Finance | Finance and Financial Management
}




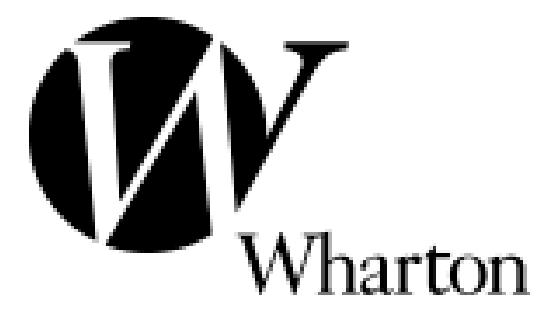

The Rodney L. White Center for Financial Research

Is the Abnormal Return Following

Equity Issuances Anomalous?

\begin{abstract}
Alon Brav Christopher Geczy

Paul A. Gompers
\end{abstract}

002-99 


\title{
The Rodney L. White Center for Financial Research \\ The Wharton School \\ University of Pennsylvania \\ 3254 Steinberg Hall-Dietrich Hall \\ 3620 Locust Walk \\ Philadelphia, PA 19104-6367
}

(215) 898-7616

(215) 573-8084 Fax

http://finance.wharton.upenn.edu/ rlwctr

The Rodney L. White Center for Financial Research is one of the oldest financial research centers in the country. It was founded in 1969 through a grant from Oppenheimer \& Company in honor of its late partner, Rodney L. White. The Center receives support from its endowment and from annual contributions from its Members.

The Center sponsors a wide range of financial research. It publishes a working paper series and a reprint series. It holds an annual seminar, which for the last several years has focused on household financial decision making.

The Members of the Center gain the opportunity to participate in innovative research to break new ground in the field of finance. Through their membership, they also gain access to the Wharton School's faculty and enjoy other special benefits.

\author{
Members of the Center \\ $1999-2000$ \\ Directing Members \\ Ford Motor Company Fund \\ Geewax, Terker \& Company \\ Miller, Anderson \& Sherrerd \\ The New York Stock Exchange, Inc. \\ Twin Capital Management, Inc. \\ Members \\ Aronson + Partners \\ Credit Suisse Asset Management \\ EXXON \\ Goldman, Sachs \& Co. \\ Merck \& Co., Inc. \\ The Nasdaq Stock Market Educational Foundation, Inc. \\ Spear, Leeds \& Kellogg \\ Founding Members \\ Ford Motor Company Fund \\ Merrill Lynch, Pierce, Fenner \& Smith, Inc. \\ Oppenheimer \& Company \\ Philadelphia National Bank \\ Salomon Brothers \\ Weiss, Peck and Greer
}




\title{
Is the Abnormal Return Following Equity Issuances Anomalous?
}

\author{
Alon Brav, Duke University \\ Christopher Geczy, University of Pennsylvania \\ Paul A. Gompers, Harvard University*
}

December 1998

\begin{abstract}
We investigate the robustness of the long-run underperformance of initial public offering (IPO) and seasoned equity offering (SEO) firms from 1975-1992. The conclusion that issuer underperformance is unique is questioned by our results. We find that underperformance is largely concentrated in the smallest issuing firms. IPO firms perform similarly to nonissuing firms matched on the basis of firm size and book-to-market ratios. SEO firm returns can be priced by four factor regression models indicating common covariation in SEO returns with nonissuing firms. Furthermore, SEO underperformance disappears for issuances beyond the first SEO. We find that the results are robust to purging benchmarks and factor returns of IPO and SEO firms.
\end{abstract}

JEL Classification: G1, G2

Key Words: Seasoned equity offerings, initial public offerings, long-run underperformance, anomalies.

\footnotetext{
* We thank Eugene Fama, Steve Kaplan, Tim Loughran, Jay Ritter, Bill Schwert, Rene Stulz, Robert Vishny, Luigi Zingales, an anonymous referee, and seminar participants at the University of Chicago and the 1995 Western Finance Association meetings for their helpful comments and suggestions. Jay Ritter graciously provided access to data on SEOs for part of his sample and Michael Bradley provided access to the SDC database. Victor Hollender and Laura Miller provided excellent research assistance. Financial support was provided by the Center for Research on Security Prices, University of Chicago and the Division of Research at the Harvard Business School. Any errors or omissions are our own.
} 


\section{Introduction}

Long-run performance anomalies have become a growth area within the academic finance literature. For example, they range from firm underperformance following mergers [Asquith (1993) and Agarawal, Jaffe and Mandelker (1992)], dividend omissions [Michaely, Thaler, and Womack (1995)], exchange listing changes [Dharan and Ikenberry (1995)] and firm overperformance following share repurchases [Ikenberry, Lakonishok and Vermaelen (1995)]. In addition, Ritter (1991), Loughran and Ritter (1995), and Spiess and Affleck-Graves (1995) show that stock market performance subsequent to initial public offerings (IPOs) and seasoned equity offerings (SEOs) is poor. Both sets of authors explain underperformance in terms of investor sentiment: investors in SEOs and IPOs systematically underreact to the bad news conveyed in an equity issue. ${ }^{1}$

This paper examines the pervasiveness of underperformance by equity issuers. We show that the underperformance can be narrowed to a smaller dimension phenomenon: IPO returns are similar to the returns on similar size and book-to-market nonissuing firms while SEO returns covary with size, book-to-market, and momentum portfolios composed of nonissuing firms. Value weighting equity issuer returns substantially reduces underperformance relative to a broad number of benchmarks. Moreover, when we match IPOs and SEOs to benchmark firms on the basis of firm characteristics and employ the Fama-French (1993) 3-factor model or the 4-factor Carhart (1997) extension of that model, we find that underperformance is not robust. These results support the analysis in Brav and Gompers (1997), which compared the performance of venture and nonventure capital-backed IPOs to

\footnotetext{
${ }^{1}$ Other papers that examine long run stock returns subsequent to issuances of corporate securities include Jegadeesh (1998) and Eckbo (1998) for equity and Spiess and Affleck-Graves (1998) for debt.
} 
various benchmarks and found that matching IPOs to similar size and book-to-market firms eliminated the underperformance.

We also examine whether our approach suffers from lack of power to detect abnormal performance as discussed in Loughran and Ritter (1998). Loughran and Ritter argue that using benchmarks and factor returns that themselves contain a large number of issuing firms reduces the power of performance tests. We find that purging benchmarks and factor returns of issuing firms, however, does not substantially change the factor regression results or the characteristics-matched performance mentioned above. In addition, we provide evidence that simple least squares regressions do not suffer from lack of power as argued in Loughran and Ritter (1998).

We also show that factor models can provide insights into potential abnormal performance that characteristics-based approaches miss, e.g., changes in riskiness that are not correlated with changes in characteristics. The time series of returns on SEO firms is highly correlated with the return on the smallest and lowest book-to-market firms which have not issued equity, indicating that their performance is not a unique issuer effect.

Furthermore, we document that SEO underperformance is not increasing in the number of offerings beyond the first. In fact, second and subsequent seasoned offerings exhibit increases in average performance compared with first issuances, with underperformance either entirely disappearing or becoming statistically, if not economically, imperceptible. The pattern of SEO performance vis a vis firm size also remains robust for subsequent issuances. 
While we are agnostic about whether covariation of equity issuer returns with a small number of portfolios is evidence of risk or sentiment, the results clearly point to the smaller dimensional issues present in the sample. Equity issuer returns are not a unique anomaly, even if they remain unexplained.

The rest of the paper is organized as follows: Section I discusses issues related to long-run performance evaluation and provides background for the methodologies used in the paper. Section II presents the data and summary statistics. Section III explores the empirical underperformance of seasoned equity offerings and initial public offerings. Section IV reviews related results. Section V concludes the paper and presents recommendations for future research.

\section{Performance tests, time horizons, trading strategies, and methodology}

In this section we present the economic framework for our analysis. We do not seek to develop new methodologies for evaluating long-run performance. Instead we hope to place this work squarely in the debate on approaches to long-run performance measurement and what we can confidently conclude from the data concerning a particular event given various approaches. Specifically, because we have no theory to guide our choice of portfolio formation and benchmark selection, the methodology used in any study implicitly takes a position in this debate, a position that is perhaps arbitrary. By comparing alternative estimation approaches, we can examine the robustness of performance measurements for equity issuers.

First, one component underpinning long-run performance tests in this and other research investigating financial market anomalies is the choice of trading strategy implicit in the performance measurement methodology. Any study taking a position on the relative performance of specific classes 
of securities must also take a position on the portfolio formation rules used to generate those returns if an aggregate measure of relative performance is to be calculated and conclusions are to be drawn from the experiment. Similarly, any performance test must have some notion of what "normal" returns are. For example, financial theory typically suggests that if there are pervasive and measurable sources of economic risk or if firm characteristics help determine the nature of expected returns, then in order to assess relative performance correctly, the researcher must match these returns to returns on benchmarks composed of firms whose fundamental riskiness or return-determining characteristics are similar to the target group.

Thus, performance tests are joint tests of the no abnormal performance null hypothesis, the formal model, and the trading rules or portfolio formation strategies invoked. While most authors recognize that abnormal performance measurement is always conditional on an asset-pricing model, there has been little effort to examine how the choice of abnormal performance measurement affects inferences. Recently, Barber and Lyons (1997), Kothari and Warner (1997), Lyons, Barber, and Tsai (1998), Brav (1998), Mitchell and Stafford (1998), and Fama (1998) have begun to fill this gap. These authors argue that the choice of a performance measurement methodology directly determines both the size and power of the statistical test. In this paper, by varying models, trading rules, and benchmarks, we contribute to the understanding of how these choices can lead to different conclusions in general and demonstrate how fragile certain aspects of the results in the literature to date actually are.

In addition, many subtle sub-issues comprise the overall performance test design conundrum. For example, conditional on any abnormal performance methodology and asset-pricing model, should sample firm returns be equal or value weighted? Obviously, under the null, this question is redundant 
yet, as Loughran and Ritter (1998) point out, the choice of the weighting scheme is important due to power considerations. To illustrate this point consider a simple scenario in which a sample contains 1,000 firms, 999 of which have a \$1 million market capitalization (the "small" firms) and one firm that has a \$1,001 million market capitalization (the "large" firm). Assume that the small firms have all underperformed by an equal percentage rate equal to $50 \%$ while the large firm has overperformed by $50 \%$. It is easy to see that an equal weighted measure of abnormal performance will indicate severe mispricing $(-50 \%)$ while value weighting will lead the researcher to conclude that the sample abnormal performance is virtually zero. Which method should we use? Indeed, the first provides strong evidence against market efficiency while the other does not.

We argue that if an alternative hypothesis suggests that small stocks are likely to be mispriced more than large stocks, then power considerations alone [Loughran and Ritter (1998))] imply the use of equal weighting. If the researcher's goal, however, is to quantify investors' average wealth change subsequent to an event -- and this seems to be the goal of most long horizon event studies -- then it follows that value-weighting is the correct method. In the above example half of the invested wealth lost $50 \%$ of its value while the second half gained $50 \%$ resulting in no net gain or loss in average wealth. Since part of our motivation is the Loughran and Ritter (1995) claim that investing in issuing firms is hazardous to investors' wealth, we believe that value-weighting generally provides the right metric from an economic point of view. Furthermore, the equal weighted approach gives a firm with a market capitalization of $\$ 1$ million the same weight in performance tests as a $\$ 1,001$ million company. It would be unusual for a large institutional investor to hold an equal weighted portfolio, so value weighted performance may provide a more useful benchmark. The prescription for investment 
strategies is quite different depending upon the weighting. Nevertheless, we also present results using equal weighting to highlight cross-sectional differences in abnormal performance wherever they are present.

Another important issue is the choice of abnormal performance measurement itself. All riskadjusting or characteristics matching strategies are not the same. For example, is a firm's risk or characteristic matched only once and then assumed to be constant through time? A second possibility is to reapply the matching procedure at the beginning of each period. The former is the generic choice of a buy-and-hold "naïve" trader. The latter is the choice of an informed trader for whom datagathering and transactions costs related to frequent trading and the costly alteration of short positions are low. We explore both methods of calculating returns in this paper.

The choice is crucial. Buy-and-hold returns may be more important for an individual, naïve investor who makes portfolio allocation choices only infrequently. Because the expected returns for a purely naïve investor are of interest to many mutual fund managers, this might argue against the idea of controlling for changing economic risk or firm characteristics through time. Large institutional investors, however, trade quite frequently and monthly portfolio rebalancing may be the relevant benchmark.

Barber and Lyon (1997), Lyon, Barber, and Tsai (1998) and Kothari and Warner (1997) provide thorough evidence regarding the specification of various abnormal performance methodologies that have been applied in previous research. While no clear winner has emerged as the universally optimal methodology in terms of statistical properties, Fama (1998) and Mitchell and Stafford (1998) have both provided additional considerations regarding the merits of such methodologies. They argue 
that abnormal performance measures such as cumulative abnormal returns (CARs) and time-series regressions at the monthly frequency, for example, are less likely to yield spurious rejections of market efficiency relative to methodologies that calculate buy-and-hold returns by compounding single period returns. First, the buy-and-hold method can magnify underperformance, even if it occurs in only a single period due to the nature of compounding single-period returns. Second, distributional properties and test statistics for cumulative abnormal returns are better understood. Loughran and Ritter (1998), however, critique the use of time-series factor models. They argue that by weighting time periods equally, as opposed to weighting events equally, these models will not capture periods of misvaluation that may affect multiple firms. They also suggest that factor models suffer from benchmark contamination, i.e., the factors used to explain returns contain the returns of issuing firms and will therefore covary with issuer portfolios by construction. ${ }^{2}$

Furthermore, a researcher should always ask whether the trading strategies upon which performance tests are built are implementable by an investor. The strategy of centering IPOs and SEOs in event-time and then measuring performance with respect to chosen benchmarks may prove to be an interesting and informative intellectual exercise. Yet, it is not necessarily a strategy that can be easily used by an investor who operates in calendar-time with less than perfect knowledge of the future. This investor would need to know in advance the number of issues to be undertaken in the future in order to fully implement this strategy, for example. In contrast to the event-time approach, calendar-time

\footnotetext{
${ }^{2}$ These authors also argue that value-weighting returns is inappropriate because small firms are more likely to be affected by misvaluation.
} 
strategies are implementable by an investor and they provide evidence on the joint temporal behavior of the firms under study.

Our approach with respect to buy-and-hold versus rebalancing techniques is to present both types of calculations taken in event time as well as calendar time and compare them. Several of our calendar time results, however, represent tests from strategies that are potentially more implementable. Nevertheless, we recognize that inference may be aided by event-time centering.

Another issue also relates to the formation of benchmarks. Simply picking one security deemed to be similar on the basis of firm-specific accounting or price-based characteristics is potentially an extremely noisy procedure for matching firm risk characteristics. Attempting to preclassify, or sort the universe of securities into portfolios representing a "smoothed" measure of the important underlying characteristic may be a better way of controlling for risk characteristics that affect expected returns. We recognize, however, that such an approach biases statistical tests of abnormal performance by inducing skewness in the distribution of return differences as noted by Lyons, Barber, and Tsai (1998). We therefore do not attempt formal statistical analyses of tests for differences in these means. Additionally, the portfolio matching method implicitly assumes that the universe of stocks from which a benchmark return is constructed is rationally priced. For example, if we believed that a subset of this universe, e.g., IPOs, and SEOs were irrationally priced, this assumption might be difficult to maintain. We present results calculated using overall universe of stocks as well as the universe of stocks purged of IPOs and SEOs and discuss benchmark-relative results with the caveats noted above in mind.

The time period over which returns are estimated can make large differences in firms' returns if risks or characteristics used in the benchmark-matching phase have a time-varying component of low 
frequency. If firms that issue equity have returns that covary with a business-cycle frequency pattern in overall returns, the information provided by a given trading strategy might actually contain few insights over short periods of time. For example, firms that issued equity in 1981-1983 may have significant covariation in returns. This is especially true if they are in the same or similar industries, have similar size, or are financed in a similar manner. Statistical tests that treat each observation independently will greatly overstate the economic significance of any performance differential and may result in the flawed inference that ignores these low-frequency characteristics of IPO and SEO underperformance.

As a second example, consider the case of small firms whose historical returns and, arguably, risks have proven to be greater than a typical large firm's returns and risks. Small firms experienced a depression of sorts in the 1980's as discussed in Fama and French (1995). Trading strategies using data from only that period, or weighted heavily in that period, may speciously determine that returns on small firms are low, especially when considering their implicit risk. In this case, the choice of time horizon and period lead to potentially erroneous conclusions as the true number of informative business cycle frequency observations is small over the trading rule's time horizon. In other words, if IPO or SEO returns are not independent, the true number of events is not the number of IPOs or SEOs.

Finally, we examine whether the performance of repeat issuers is any different from the performance of firms that undertake an SEO for the first time. We therefore conduct separate tests for firms undertaking SEOs for the first time and for those which raise capital in a second and subsequent SEOs and examine their performance independently.

\section{Data}


Our sample of seasoned equity offerings was identified in the Investment Dealers' Digest of Corporate Financing for the period 1975-1992. Jay Ritter provided data on seasoned equity offerings for the period 1975-1984. For inclusion in our sample, a firm performing a seasoned equity offering must be followed by CRSP sometime after the offering date. Our sample includes 4,526 offerings made by 2,772 firms. ${ }^{3}$ Figure 1 gives the time series of SEOs in our sample. The pattern shows clear evidence of clustering. For example, times of active seasoned issuance are also active IPO markets (Figure 2). Unlike an IPO in which a firm by definition can only go public once, many firms in our sample are multiple issuers. $1,783(64.3 \%)$ firms perform only one seasoned equity issue; 614 (22.2\%) issue twice; $211(7.6 \%)$ issue three times; $81(2.9 \%)$ issue four times; $35(1.3 \%)$ issue five times; 17 $(0.6 \%)$ issue six times; and $31(1.1 \%)$ issue seven times or more. Figure 1 also shows the distribution of issues by exchange. In the 1970s, most SEOs were New York Stock Exchange (NYSE) firms. Over the sample period, however, NASDAQ firms began to account for a larger fraction of issuances.

Our sample of initial public offerings is collected from various issues of the Investment Dealers' Digest of Corporate Financing for the period 1975-1995 as well as from the Securities Data Corporation database. For inclusion in our sample, a firm performing an IPO must be followed by the Center for Research in Securities Prices (CRSP) at some point after the offering date. Our final sample includes 4,622 IPOs for the period 1975-1992.

Our data set is slightly different from those of Loughran and Ritter (1995) and Spiess and Affleck-Graves (1995) in several ways. First, unlike Loughran and Ritter, we exclude all unit offerings

\footnotetext{
${ }^{3}$ We include all seasoned equity offerings, both pure primary share offerings and combination primary and secondary share offerings.
} 
from our sample because separating the value of the offerings' components (usually common stock with warrants) is difficult. We also choose to include utilities in our sample even though Loughran and Ritter exclude them. The potential impact of including utilities is small for two reasons. First, they comprise only $5.5 \%$ of either sample. Second, in unreported results we reestimated our results excluding utilities and the results were qualitatively identical. In addition, unlike Spiess and AffleckGraves who look only at offerings that are entirely primary shares, we include offerings that also have a secondary component in which management sells some of their shares in the offering, i.e., we include both pure primary offerings and combination primary and secondary offerings. If, as Myers and Majluf (1984) suggest, managers attempt to sell their shares when they perceive them to be overvalued, then inclusion of these issues may reinforce the long-run underperformance effect we find in the data as the market revises its assessment of these firms' prospects. Including secondary issues along with primary issues is conservative in this sense. We do not expect that the differences between our sample and those of Loughran and Ritter (1995) and Spiess and Affleck-Graves should impart any particular biases to our conclusions.

In the analyses that follow, we examine the size and book-to-market characteristics of our sample. Starting in January of 1964, we use all New York Stock Exchange (NYSE) stocks to create size quintile breakpoints. ${ }^{4}$ Size is measured as the number of shares outstanding times the stock price at the end of the preceding month. We obtain our accounting measures from the COMPUSTAT quarterly and annual files and define book value as book common equity plus balance sheet deferred

\footnotetext{
${ }^{4}$ Fama and French (1992) use only NYSE stocks to create the breakpoints in order to ensure dispersion in the characteristics across portfolios. Like Fama and French, however, our benchmarks allocate all stocks (NYSE, American Stock Exchange (ASE), and NASDAQ) to one of the 25 portfolios.
} 
taxes and investment tax credits for the fiscal quarter ending two quarters before the sorting date. This is the same definition as in Fama and French (1992). If the book value is missing from the quarterly statements, we search for it in the annual files. ${ }^{5}$ We form book-to-market quintile breakpoints using only NYSE firms and then form $25(5 \times 5)$ size and book-to-market portfolios by intersecting the portfolio breakpoints and allocating all firms into these portfolios. ${ }^{6}$

These breakpoints also create 25 portfolios to which each SEO or IPO firm can be assigned. For the sample of SEO firms, we calculate the market value of the firm one month prior to the issuance. For IPO firms, we calculate the market value of equity at the first month after the offering. We calculate book values using Compustat data. Book values for SEO firms are six months prior to the offering to allow for reporting lag. For book value of equity of IPO firms we use COMPUSTAT and record the first book value after the IPO as long as it is within eighteen months of the offering month ${ }^{7}$. The bias in book value should not be too great because the increment in book value due to retained earnings in the first year is likely to be very small for newly public companies.

Table 1 presents the size and book-to-market portfolio distribution for the IPO sample. IPOs are heavily weighted in the small, low book-to-market portfolios. Over half (51.8\%) of the IPO firms are in the smallest, lowest book to market portfolio (i.e., the $(1,1)$ portfolio). Two thirds of the IPO firms are in the smallest quintile of stocks. Similarly, less than $1 \%$ of the IPOs are in the largest quintile

\footnotetext{
${ }^{5}$ For firms that are missing altogether from the quarterly files, we use the annual files.

${ }^{6}$ We do not include stocks with negative book values.

${ }^{7}$ Shortening this interval does not affect any of the results that we report later although it leads to a smaller sample size.
} 
of stocks when breakpoints are defined by NYSE firms. In terms of book-to-market ratios, over $77 \%$ of the IPO firms have book-to-market ratios in the lowest quintile when breakpoints are defined by NYSE stocks.

It is not surprising that the sample tends to have this bias. Smaller firms may generate less internal cash and may thus need to issue equity to finance expansion. Similarly, managers of smaller firms may have substantially larger equity stakes in the firms and want to reduce their holdings via secondary offerings. The low book-to-market grouping may be explained in one of two ways. First, the low book-to-market ratios may represent future growth options. These firms are "growth" firms and may have many good investment opportunities for which they need to raise cash. On the other hand, the low book-to-market ratio for these firms may just be an indicator of relative overpricing. Loughran and Ritter (1995) argue that issuers time the market for new shares when their firms are relatively overvalued.

We present summary statistics for the SEOs in Table 2 where we show the distribution of SEO firms by their ranking in the $5 \times 5$ size and book-to-market portfolios. While the SEO sample is heavily weighted in the smallest and the lowest book-to-market firms, it is substantially more evenly distributed than the IPO sample. Only $24 \%$ of the SEO sample is in the $(1,1)$ portfolio, less than half the fraction of IPO firms that fall in the $(1,1)$ portfolio. Almost $8 \%$ of the seasoned equity-issuing firms are in the largest quintile of NYSE stocks and twice as many SEO firms are outside of the lowest book-tomarket quintile. These differences lead us to examine the performance of IPO and SEO firms separately. 


\section{Underperformance of Equity Issuers}

\section{A. Full Sample Results}

We utilize various benchmarks to measure SEO and IPO long-run performance throughout this paper. First, the performance of issuing firms is matched to several broad market indexes. The S\&P 500, NASDAQ composite index, CRSP value weighted index, and CRSP equal weighted index are all compared to equity issuer performance. ${ }^{8}$

We also create control samples which will be assumed to represent "normal" returns by matching issuing firms with groups of firms drawn from the universe of stocks based on firm characteristics. These characteristics are firm size and book-to-market or size, book-to-market, and price momentum portfolios. We form size and book-to-market portfolios as described in the previous section. ${ }^{9}$ We create the 25 size and book-to-market portfolios each quarter. In order to eliminate the benchmark bias discussed in Loughran and Ritter (1998), we eliminate all IPO and SEO firms from the benchmark portfolios. We do this for a period of five years after their issuance. Equal weighted returns are calculated for each portfolio for the next three months. We repeat the above procedure for January, April, July, and October of each year.

Momentum breakpoints are calculated as follows. Starting in January 1964, we first form size quartile breakpoints using NYSE firms only. Then, within each size quartile we form quartile book-to-

${ }^{8}$ CRSP equal- and value-weighted indexes include all stocks listed on the NYSE, ASE, and NASDAQ.

${ }^{9}$ While breakpoints are based only on NYSE stocks, all CRSP-listed stocks are allocated to one of the 25 portfolios. 
market breakpoints that are in turn split further into quartile momentum breakpoints. Size and book-tomarket are calculated as described in the previous paragraph. Momentum is calculated as the buy and hold return over the previous year excluding the month before the sorting date. This sorting procedure results in $64(4 \times 4 \times 4)$ possible portfolios into which we allocate the entire universe of CRSP-listed firms (i.e., all NYSE, ASE, and NASDAQ stocks), a manageable number that maintains a level of aggregation comparable to previous studies. ${ }^{10}$ Unlike the portfolio formation based on accounting measures, we repeat the momentum-based formation process monthly. For each of the 64 portfolios, we calculate equal weighted monthly returns.

Table 3 presents long-run performance for the sample of SEOs from an event time strategy in which each SEO constitutes an event. Panel A calculates buy-and-hold returns. To construct our figures, we use the monthly tapes and follow each offering beginning in the month after the event for the earlier of 60 months or the delisting month. Our buy-and-hold intervals are set to match those chosen by Loughran and Ritter (1995).

On the left-hand side of Panel A, we equal weight the returns of the SEOs and their benchmarks. Loughran and Ritter (1995) and Spiess and Affleck-Graves (1995) calculate wealth relatives for the five year period by taking the ratio of one plus the equal weighted return on the SEO

${ }^{10}$ We use only quartile breakpoints when we form size, book-to-market, and momentum benchmarks because finer divisions of firms (i.e., quintiles) leave certain portfolios with very few stocks. 
portfolio over one plus the equal weighted return on the chosen benchmark. We also report the average excess return of the SEO over the chosen benchmark.

The wealth relatives in Panel A are very similar to those in Loughran and Ritter and Spiess and Graves. The five-year wealth relative is less than 1.0 for all benchmarks, ranging from 0.84 to 0.89 . The five-year excess returns are all negative, anywhere from $-19.5 \%$ versus the NASDAQ Composite index to $-30.1 \%$ versus the S\&P 500 index.

Unlike Ritter and Loughran, we make no attempt to match SEOs to individual firms. Loughran and Ritter (1995) match firms on size. They also require the matching firm to be a nonissuing firm for at least five years. Therefore, because NASDAQ returns are picked up by CRSP in 1972, 1978 is the first year that any NASDAQ firm can be used as a matching firm in their study. As Table 2 shows, most issuing firms tend to be small. By matching the early sample to small NYSE/ASE firms, Loughran and Ritter may be matching SEO firms to the DeBondt and Thaler $(1985,1987)$ long-term loser firms that we know outperform similarly sized firms. Their benchmark therefore may be biased towards finding underperformance. We avoid this potential problem.

The right half of panel A presents value weighted results for our sample. As mentioned previously, value weighted performance may be an economically more meaningful construct than equal weighted performance. In Panel A, value weighting reduces underperformance, but does not do away with it. Wealth relatives are now between 0.87 and 0.93 and the excess return is between -14.2 and 25\%. This indicates that small issuers underperform more than large issuers.

In Panel B of Table 3, we calculate the cumulative abnormal returns (CARs) for the five years following the issuance. The CARs are all substantially less than the excess returns calculated in Panel 
A. In fact, the average CARs are between $-8 \%$ and $-17 \%$ in the value weighted SEO sample. While value weighting increases CARs relative to the broad market benchmarks, there is little change in performance relative to the size and book-to-market or size, book-to-market, and momentum portfolios. The results in Table 3 clearly show that the underperformance of SEO firms is magnified by the calculation of buy-and-hold returns.

The returns of the IPO sample are similarly explored in Table 4. Once again, we present buyand-hold returns in Panel A and cumulative abnormal returns in Panel B. The results are similar in both panels. On an equal-weighted basis, IPO firms underperform broad market benchmarks by a wide margin, underperforming the S\&P by $44 \%$ and NASDAQ by $31 \%$. Value weighting the IPO firm returns cuts this underperformance in half. Once IPO firm returns are matched to size and book-tomarket portfolios, which are themselves free of issuing firms, there is no underperformance. Average excess returns are actually positive. As Brav and Gompers (1997) show, initial public offering firms have returns that are comparable to similar, nonissuing size and book-to-market firms.

As we will see later, the reason that matching to size and book-to-market eliminates the underperformance of the IPO firms but not the SEO firms is that the vast majority of IPO firms are in the $(1,1)$ portfolio; that is, the smallest, lowest book to market portfolio. Small, growth firms do particularly poorly following heavy periods of equity issuances. SEO firms have a flatter distribution of size and book-to-market across fractiles, and hence the size and book-to-market benchmark is not primarily the $(1,1)$ portfolio.

\section{B. Factor regression analysis}


The characteristics-based approach of the previous section assumes that the relevant risk of firms is captured by some set of observable firm-specific characteristics, e.g., size, book-to-market, and momentum. If these observable characteristics are only imperfect proxies for some true underlying factors, then the characteristics-based approach might misclassify firms' riskiness. Fama (1998) argues that factor-based approaches to performance evaluation as documented in Fama and French (1993) are more appropriate tests of performance. In the Fama-French (1993) model the first factor is the excess return on the value weighted market portfolio. The second factor is a factor-mimicking portfolio, $\mathrm{SMB}$, the return on a zero investment portfolio formed by subtracting the return on a large firm portfolio from the return on a small firm portfolio. ${ }^{11}$ Similarly, a second factor mimicking portfolio, HML, is the return on a zero investment portfolio and is calculated as the return on a portfolio of high book-to-market stocks less the return on a portfolio of low book-to-market stocks. ${ }^{12}$ In the tests to follow, the Fama-French 3-factor model plays a central role.

Carhart (1997) explores extensions of the Fama-French model. In particular, he argues that a fourth factor can increase the explanatory power of the Fama-French model when one examines the returns of mutual funds. Carhart's fourth factor is based on ranking firms by their return over the previous year, i.e., their momentum. This is based on the empirical observation that firms having high returns in the previous year tend to continue to enjoy high returns in the next year. We do not take a position on the distinction between momentum as a contemporaneous factor or as conditioning

\footnotetext{
${ }^{11}$ The breakpoints for small and large are determined by NYSE firms alone, but the portfolios contain all firms traded on NYSE, ASE, and NASDAQ exchanges.

${ }^{12}$ The high book-to-market portfolio represents the top $30 \%$ of all firms on COMPUSTAT while the low book-to-market portfolio contains firms in the lowest $30 \%$ of the COMPUSTAT universe of firms.
} 
information. His factor, PR12, is formed by taking the return on high momentum stocks minus the return on low momentum stocks. ${ }^{13}$

As discussed in Section II, however, Loughran and Ritter (1998) argue that factor models often suffer from factor contamination and, hence, have low power for determining underperformance. Specifically, if factor returns are calculated using, in part, the returns of the sample being tested for underperformance (e.g., IPOs or SEOs), it is likely that the factor returns will "explain" that underperformance. To deal with this potential for factor contamination, we run our factor regressions using factor returns calculated using all CRSP-listed securities as well as using only those firms which have not issued equity in an IPO or SEO within the last five years, i.e., issuer-purged factor returns. The latter set of factor regressions does not suffer from factor contamination.

We interpret the intercept in Fama-French three and four-factor model time series regressions as an indictor of risk-adjusted performance for candidate portfolios. This measure has a role analogous to Jensen's alpha in the CAPM framework. To benchmark the full sample and issuer purged factor regressions, Table 5 presents four factor regression results for the 25 size and book-to-market portfolios discussed previously. ${ }^{14}$ In Panel A, the full sample factors do a reasonable job of pricing nearly all of the test portfolios. Much like in the earlier Fama and French (1993) results, the four factor model has difficulty pricing the $(1,1)$ portfolio, i.e., the smallest, lowest book-to-market firms, which has a large negative intercept of $-0.0053,53$ basis points per month.

\footnotetext{
${ }^{13}$ Momentum here is defined as the previous 11 month nominal stock return lagged one month. We create the factor breakpoints by taking the average return on the top $50 \%$ of all firms (winners) minus the return on the bottom $50 \%$ of all firms (losers).
} 
In Panel B, the purged factor returns appear to price the test portfolios almost as well as the full sample returns. While the coefficients do change slightly, there is no dramatic shift in the intercepts from Panel A. The purged factors still have difficulty pricing small, growth companies. The largest effect of purging the factor returns is on the PR12 coefficients. It seems that issuing firms contribute significantly to PR12 returns. Similarly, the adjusted $\mathrm{R}^{2} \mathrm{~S}$ are slightly smaller in all the regressions with the purged factor returns, although the models continue to explain the vast majority of the time series of returns.

Table 6 presents the three and four factor regressions for various SEO portfolios using both the full sample factor returns (Panel A) and the issuer purged factor returns (Panel B). The results in Panel A show that both the three and four factor regressions have difficulty pricing the equal-weighted SEO portfolio returns. Once returns are value weighted, however, intercepts in three and four factor regressions become small and we are unable to statistically distinguish them from zero. If issuers are broken down by size tercile, only the smallest size tercile displays significant underperformance with an intercept of $-0.0069,69$ basis points per month. Interestingly, all SEO portfolios load negatively on PR12, i.e., they covary with low momentum stocks. This is one reason that matching the buy-and-hold returns on the basis of momentum in Table 3 did not lower the underperformance. SEO firms are actually high momentum stocks prior to issuing. The average stock return in the year prior to issuance is $76 \%$. But in the period immediately following the SEO, their returns look like the returns of low momentum stocks. The results in Panel B with the purged factors are qualitatively similar to the full

\footnotetext{
${ }^{14}$ These 25 portfolios contain all CRSP-listed firms.
} 
sample results. It therefore does not appear that a large portion of the explanatory power of the FamaFrench model comes from factor contamination as Loughran and Ritter (1998) claim.

We present similar results for IPO firms in Table 7. The results here are even stronger. In the three factor regressions, only the equal weighted and smallest tercile returns show any underperformance. Intercepts for the value weighted and large portfolios are small and insignificant. The four factor results, however, show that even the equal weighted portfolio and the smallest IPO firm returns can be priced. Intercepts are insignificant in all of the four factor regressions.

The results of Tables 6 and 7 are not meant to imply that there is no underperformance. The interpretation of Fama-French regression results is not without controversy. What these results do show, however, is that the returns of SEO and IPO firms have common covariation with other, nonissuing firms.

\section{Repeat Issuers}

We next undertake an analysis of the robustness of the performance measurements. In particular, we examine whether the first issuance by a firm performs differently from the second or subsequent equity issuance. In Table 8 we divide seasoned equity offerings into the first issuance for a firm during our sample period (including those firms that only do one offering) and second or subsequent offerings. While this strategy is contingent upon a starting point in the data, it does not use future information with respect to portfolio formation. We expect that if firms are timing the market when they issue equity, the performance should be similar for first and subsequent offerings. Under the 
market timing hypothesis, the only firms willing to sell equity are those that are overvalued by the market.

We find, however, that their performance differs dramatically. First issuances consistently perform worse than subsequent offerings. In three (unreported) and four factor regressions, intercepts for the sample of first issuances are negative and significant. For the equal weighted full sample of first time issuers, the intercept is $-0.0033,-33$ basis points per month. The smallest tercile of issuers has an

Second and subsequent issuers, however, never have a statistically significant intercept. The equal weighted returns show an insignificant intercept of $-0.0012,-12$ basis points per month. Even the smallest tercile of issuers has an intercept that is insignificantly different from zero (with a t-statistic of -1.89). The pervasiveness of SEO underperformance is therefore not universal. Only the first equity issuance shows substantial underperformance. Any explanation of SEO underperformance needs to account for the differential performance of these two groups. ${ }^{15}$

\section{Calendar time returns}

Much of the underperformance literature examines issues in event time, i.e., they treat each issuance as an independent observation. We know, however, that issuing firms have many common characteristics. Brav (1998) has shown that correcting for cross sectional correlation can substantially affect the reported significance levels of underperformance. To illustrate the common co-movements, we undertake calendar time returns calculations.

${ }^{15}$ The repeat issuer results excluding utilities are qualitatively identical to those reported here. 
In Figure 3, we calculate a time-series regression of its excess return on the Fama and French factors including Carhart's momentum factor for each sample firm. We use the version of the factors that have been purged of issuers. From each such regression we keep the intercept and residuals. We calculate size breakpoints (small, medium and large) each month using market capitalizations known at the beginning of the month and plot the equal weighted cumulative sum of these estimates for the three size sorts. As the figure shows, the smallest tercile of issuers has consistently negative performance relative to similar size, book-to-market, and momentum firms that have not issued equity.

The medium and large issuers, however, do not exhibit substantial underperformance over the entire sample period. The medium and large firms do, however, substantially decline in value relative to the benchmarks between 1983 and 1984. This is the same period that Brav and Gompers (1997) show that IPO firms also underperformed. Fama and French (1995) argue that a potentially unexpected earnings shock affected small, growth companies in the early and mid-1980s. It is possible that equity issuers are particularly affected by these low-frequency shocks.

Finally, recall that one of the criticisms that Loughran and Ritter (1998) level against the FamaFrench time-series approach is that the method weights each calendar month equally rather than taking into account the number of observations in each month. They argue that months where a large number of SEO firms underperform are not weighted appropriately by the time-series regressions. Since the cumulative abnormal return described above is an average of individual SEO abnormal returns, their critique does not apply here. It can be seen that for the large and medium size terciles the exact number of observations in each month is nearly redundant. Apart from a one-year period of underperformance, 
both graphs are nearly flat, indicating that weighting the calendar months equally does not lead to reduced power to reject the null hypothesis of no underperformance.

\section{Related Research: What Do We Know?}

The empirical finance literature has recently developed a large number of "performance anomalies" that various authors have suggested are present in financial markets. Fama (1998) critiques many of these studies and their methodologies. Our paper is part of a growing literature [see, for example, Brav (1998), Mitchell and Stafford (1998), and Eckbo (1998)] that calls into question the claim that many independent anomalies exist. In this section, we provide further evidence that the many of the performance anomalies are actually examining the same return phenomenon. Second, we show that the time series of returns on even small seasoned equity offering firms is not unique.

\section{A. Post-listing stock returns}

Dharan and Ikenberry (1995) examine the long-run performance of firms following moving from NASDAQ to either the American Stock Exchange (ASE) or New York Stock Exchange (NYSE). They find that performance subsequent to moving exchange listings is particularly bad. For all firms moving to a new exchange from 1973 to 1992, the cumulative abnormal return relative to size and book-to-market benchmarks is $-7.02 \%(\mathrm{t}=-2.78)$. They also examine whether an IPO or SEO within two years of the listing affects this measured underperformance. Nonissuers, according to Dharan and Ikenberry's definition, performed like issuing firms. 
While we do not replicate all the tests in their paper, we reexamine whether the post-listing drift is specifically due to an issuer effect. In Table 9 we examine the three-year cumulative abnormal returns for firms which move from ASE to the NYSE or from NASDAQ to the NYSE or ASE. We use size and book-to-market portfolios as benchmarks to calculate abnormal returns. ${ }^{16}$ For the entire sample of firms, the mean cumulative abnormal return over the five years following exchange listing is $-12.1 \%$. Performance is universally poor regardless of where the firm lists.

We also calculate the abnormal returns of post-listing firms, but exclude all firms that have done an IPO or SEO within the last five years. Loughran and Ritter (1995) show that much of the effect of poor long-run performance after an IPO or SEO occurs in years three through five, postissuance. When the five year cut-off is used (instead of the two year cut-off used by Dharan and Ikenberry (1995)), 389 firms are dropped from the post-listing sample, i.e., 389 firms move exchanges within five years of an SEO or an IPO. Once the five-year cut-off is used, the negative post-listing drift looks quite meager. The magnitude of the decline is nearly half of what it was in the entire sample. Firms that move from Nasdaq to NYSE now have a positive cumulative abnormal return. As the six month period breakdown shows, much of the post-listing drift occurs after eighteen months postlisting. Through a year and a half after the move, CARS are $-0.85 \%$ for all firms that move excluding issuers and only $-2.00 \%$ for firms that move from Nasdaq to the ASE. It is hard to build a reasonable model in which it takes two years for mispricing to become known. The post-listing "anomaly" is therefore probably best understood as another facet of issuer performance.

\footnotetext{
${ }^{16}$ The choice of the long-horizon return interval and the benchmark follows Dharan and Ikenberry's setup.
} 


\section{B. Uniqueness of issuer performance}

The results above show, along with those in Brav and Gompers (1997), that matching IPOs on the basis of size and book-to-market benchmarks eliminates their underperformance. In other words, IPO firms have returns that mirror similar size and book-to-market firms. The SEO results, however, show that size and book-to-market benchmarks do not eliminate underperformance. Small SEOs continue to underperform.

The difference between the IPO and SEO results, however, largely stems from the concentration of IPOs in the $(1,1)$ portfolio, i.e., most IPOs are in the smallest, lowest book-to-market portfolio which has particularly bad returns after periods of heavy equity issuance. SEO firms, however, are more evenly distributed. It is possible, however, that SEO firms share return patterns with IPOs and small, low book-to-market nonissuing firms. This might occur because observable characteristics are only imperfectly correlated with a firm's loading on risk factors.

In Table 10, we examine the time series of returns on a zero investment portfolio that invests in firms which have done a seasoned equity offering within the last five years and shorts firms in the $(1,1)$ portfolio (excluding IPO and SEO firms). If the returns of SEOs and $(1,1)$ nonissuing firms are highly correlated, the intercept in Fama-French factor regressions should be zero and the slope coefficients should be close to zero. If the returns of SEOs and small, growth companies are highly correlated, there ought to be nothing left to explain. This zero investment portfolio will simply have a return that is close to white noise. 
The above prediction is born out in the results. In Table 10, the full sample zero investment portfolio has a positive intercept in both three and four factor regressions, although they are insignificant. Explanatory power of the model is very low, with adjusted $\mathrm{R}^{2} \mathrm{~s}$ of $28 \%$. When we look at the smallest tercile of issuers, the group for which we could not explain performance above, the intercepts are insignificantly different from zero. Furthermore, slope coefficients are small and the adjusted $\mathrm{R}^{2} \mathrm{~s}$ are $7 \%$ and $13 \%$ for the three and four factor model respectively. This indicates that the returns of the smallest SEO firms are highly correlated with the returns of $(1,1)$ firms that have not issued equity. ${ }^{17}$

Section III results indicated that the smallest SEO returns were difficult to explain. Table 10, however, shows that even the performance of the smallest SEOs is not unique. The time series of their returns is highly correlated with the return of small, growth companies (which have not issued equity) even though the SEO firms are not in the $(1,1)$ portfolio. These results also highlight some of the potential pitfalls of characteristic-based approaches to performance evaluation. If the characteristic is not perfectly correlated with the factor loading or source of performance premium (or discount), characteristic-based performance tests can lead to erroneous results.

\section{Conclusions}

The results from this paper shed light on previous studies that have documented underperformance of firms issuing equity. We have shown that IPO firm returns are similar to size and

17 The simple correlation between the monthly excess return (over the market) of 1,1 portfolio and the smallest SEO tercile is $0.867(\mathrm{p}=0.000)$, between the 1,1 and the middle tercile is 0.625 $(\mathrm{p}=0.000)$, and between the 1,1 and the largest tercile of SEOs is $0.101(\mathrm{p}=0.129)$. 
book-to-market firms that have not issued equity. Value weighted portfolios of SEO firms show small economic underperformance. Our results are robust to purging the benchmarks and factor returns of issuers.

Recent papers by Teoh, Welch, and Wong (1998a,b) and Lee (1997) indicate that various attributes of the IPO or SEO can predict which issuers will underperform. Teoh et al. (1998a,b) find that a higher level of discretionary accruals prior to issuance, potentially to boost earnings, is associated with poorer post-issue performance. Lee (1997) shows that SEOs in which managers do not sell equity, i.e., primary issues, perform worse than SEOs in which managers sell some of their equity holdings. Our results are consistent with their findings. Firms with higher levels of discretionary accruals and issue primary shares tend to be the smaller IPO and SEO firms, so it is not unsurprising that their measures are correlated with relative performance.

Our results also support the notion that many of the long-run anomalies found in the finance literature are manifestations of the same returns' pattern in the data. Various types of corporate decisions or subsamples of firms may be more heavily weighted in the types of firms that underperform without the decision or event being the cause of underperformance. If one separates a sample into various groups, one part of the sample is very likely to underperform. In fact, we have shown that the post-listing result of Dharan and Ikenberry (1995) is largely caused by issuing firms in their sample. We have also shown that the time series of issuing firm returns, both IPO and SEO firms, are similar to those of small, growth firms which have not issued equity. In other words, equity issuers' return patterns are not unique. They are part of more systematic price movements. 
Financial economists interested in examining long-run performance should retain factor models as an evaluative tool. Loughran and Ritter's (1998) critiques of factor models clearly need to be considered when evaluating performance. We have shown, however, that characteristic-based approaches can suffer from various pitfalls as well. Without a clear theory to guide the choice of portfolio formation rules or proper risk-adjustment, a thorough study of performance must employ both approaches.

Our results are consistent with both behavioral finance and equilibrium rational asset pricing interpretations. Like Fama (1998), our results may simply imply that we do not yet have the correct model of returns. The ability to narrow the underperformance or explain it with various factor models is evidence in that direction. A behavioral explanation would suggest that investor sentiment is a wider phenomenon, affecting a large number of firms in the market simultaneously. While we do not offer such a "unified theory" of behavioral finance, we believe our results point to the need for such a theory. Papers like Daniel, Hirshleifer, and Subrahmanyam (1998) and Barberis, Shleifer, and Vishny (1998) seem ad hoc in their approach to behavioral modeling. The sentiment in their models is firm-specific. Behavioral models should be more general and generate testable empirical predictions, much like equilibrium asset pricing models. 


\section{References}

Agarawal, Anup, Jeffrey Jaffe, and Gershon Mandelker, 1992, The post-merger performance of acquiring firms: A re-examination of an anomaly, Journal of Finance 47, 1605-1621.

Asquith, Paul, 1983, Merger bids, uncertainty, and stockholder returns, Journal of Financial Economics 11, 51-83.

Asquith, Paul, and Lisa Meulbroek, 1994, An empirical investigation of short interest, MIT and Harvard University working paper.

Asquith, Paul, and David Mullins, 1986, Equity issues and offering dilution, Journal of Financial Economics 15, 61-89.

Barber, Brad, and John, Lyon, 1997, Detecting long-run abnormal stock returns: The empirical power and specification of test statistics, Journal of Financial Economics 43, 341-372.

Barberis, Nicholas, Andrei Shleifer, Robert Vishny, 1998, A model of investor sentiment, Journal of Financial Economics 49, 307-345.

Brav, Alon, 1998, Inferences in long-horizon event studies: A Bayesian approach with applications to initial public offerings, Duke University working paper.

Brav, Alon, and Paul A. Gompers, 1997, Myth or Reality? The Long-Run Underperformance of Initial Public Offerings: Evidence from Venture Capital and Nonventure Capital-backed Companies, Journal of Finance 52, 1791-1822.

Carhart, Mark, 1997, On Persistence in Mutual Fund Performance," Journal of Finance 52, 5782.

Daniel, Kent, David Hirshleifer, and Avanidhar Subrahmanyam, 1998, A theory of overconfidence, self-attribution, and security market under- and over-reactions, Journal of Finance 53.

De Bondt, Werner, and Richard Thaler, 1985, Does the Stock Market Overreact?, Journal of Finance 40, 793-808.

De Bondt, Werner, and Richard Thaler, 1987, Further evidence on investor overreaction and stock market seasonality, Journal of Finance 42, 557-581.

Dharan, Bala, and David Ikenberry, 1995, The long-run negative drift of post-listing stock returns, Journal of Finance 50, 1547-1574. 
Eckbo, Espen, and Ronald W. Masulis, 1998, The conditional long-run performance of security offerings: Is there a "new issues puzzle"? Dartmouth College working paper

Fama, Eugene, The Foundations of Finance, Basic Books, 1976.

Fama, Eugene, 1998, Market efficiency, long-term returns, and behavioral finance, Journal of Financial Economics 49, 283-306.

Fama, Eugene, and Kenneth French, 1992, The cross-section of expected stock returns, Journal of Finance 47.

Fama, Eugene, and Kenneth French, 1993, Common risk factors in the returns of stocks and bonds, Journal of Financial Economics 33, 3-55.

Fama, Eugene, and Kenneth French, 1995, Size and book-to-market factors in earnings and returns, Journal of Finance 50, 131-156.

Fama, Eugene, and Kenneth French, 1996, Multifactor explanations of asset pricing anomalies, Journal of Finance 51, 55-84.

Grundy, Bruce D., and J. Spencer Martin, 1998, Understanding the Nature of the Risks and the Source of the Rewards to Momentum Investing, University of Pennsylvania working paper.

Ikenberry, David, Josef Lakonishok, and Theo Vermaelen, 1995, Market underreaction to open market share repurchases, Journal of Financial Economics 39, 181-208.

Jegadeesh Narasimhan, 1998, Long-Run Performance of Seasoned Equity Offerings: Benchmark Errors and Biases in Expectations, University of Illinois at Urbana Champaign working paper.

Kahneman, D., and A. Tversky, 1982, Intuitive prediction: Biases and corrective procedures, In D. Kahneman, P. Slovic, and A. Tversky (eds.), Judgement under Uncertainty: Heuristics and Biases, London: Cambridge University Press.

Kothari, S.P., and Jerold Warner, 1997, Measuring long horizon security price performance, Journal of Financial Economics 43, 301-339.

Lakonishok, Josef, Andrei Shleifer, and Robert Vishny, 1994, Contrarian investment, extrapolation, and risk, Journal of Finance 49, 1541-1578.

Lee, Inmoo, 1997, Do Firms Knowingly Sell Overvalued Equity? Journal of Finance 52, 1439-1466.

Loughran, Tim, and Jay Ritter, 1995, The new issues puzzle, Journal of Finance 50, 23-51. 
Loughran, Tim, and Jay Ritter, 1998, Uniformly least powerful tests of market efficiency, University of Florida working paper.

Lyon John, Brad Barber, and Chih-Ling Tsai, 1998, Improved methods for tests for long run abnormal stock returns, Journal of Finance, forthcoming.

Michaely, Roni, Richard Thaler, and Kent Womack, 1995, Price reactions to dividend initiations and omissions, Journal of Finance 38, 1597-1606.

Mikkelson, Wayne, and M. Megan Partch, 1986, Stock price effects and costs of secondary distributions, Journal of Financial Economics 15, 31-60.

Mitchell, Mark, and Erik Stafford, 1998, Managerial decisions and long-term stock price performance, University of Chicago working paper.

Myers, Stewart, and N.S. Majluf, 1984, Corporate financing and investment decisions when firms have information that investors do not have, Journal of Financial Economics.

Ritter, Jay, 1991, The long-run performance of initial public offerings, Journal of Finance 42, 365-394.

Shleifer, Andrei, and Robert Vishny, 1997, The limits to arbitrage, Journal of Finance 52, 35-55.

Spiess, Katherine, and John Affleck-Graves, 1995, The long-run performance following seasoned equity issues, Journal of Financial Economics, 38, 243-267.

Spiess, Katherine, and John Affleck-Graves, 1998, The long-run performance following public bond issues, Forthcoming in the Journal of Financial Economics.

Teoh, Siew, Ivo Welch, and T.J. Wong, 1998a, Earnings management and the long-run underperformance of seasoned equity offerings, Journal of Financial Economics 50, 63-100.

Teoh, Siew, Ivo Welch, and T.J. Wong, 1998b, Earnings management and the long-run underperformance of initial public offerings, Journal of Finance, forthcoming. 


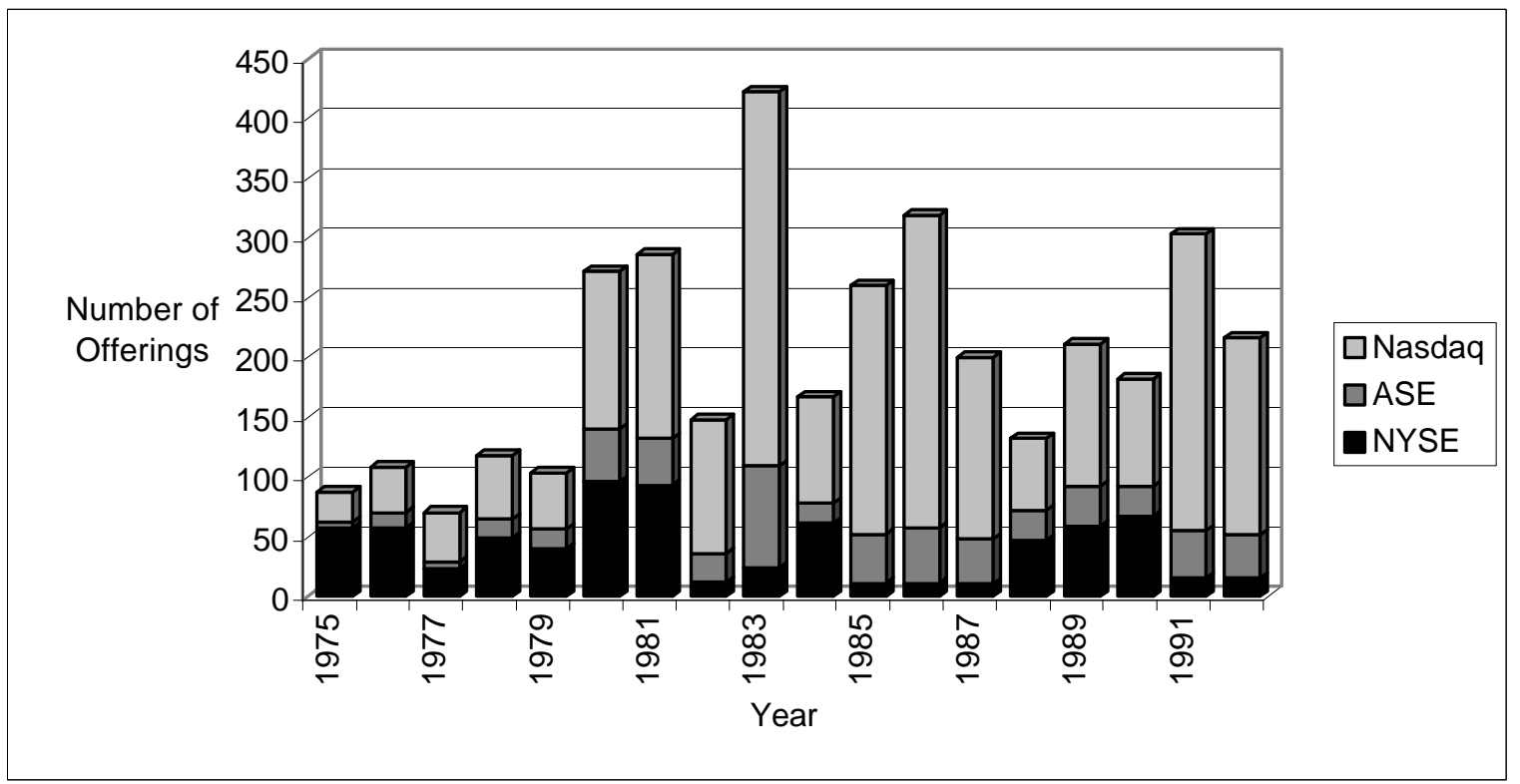

Figure 1 Time Series of Seasoned Equity Offerings Listed by Exchange at Time of Offering. The sample of seasoned equity offerings was identified in the Investment Dealers' Digest of Corporate Financing for the period 19751992. Jay Ritter provided data on seasoned equity offerings for the period 1975-1984. For inclusion in our sample, a firm performing a seasoned equity offering must be followed by CRSP sometime after the offering date. The sample includes 4,526 offerings made by 2,772 firms. Offerings are listed by the exchange on which the firm was trading at the time of the offering. 


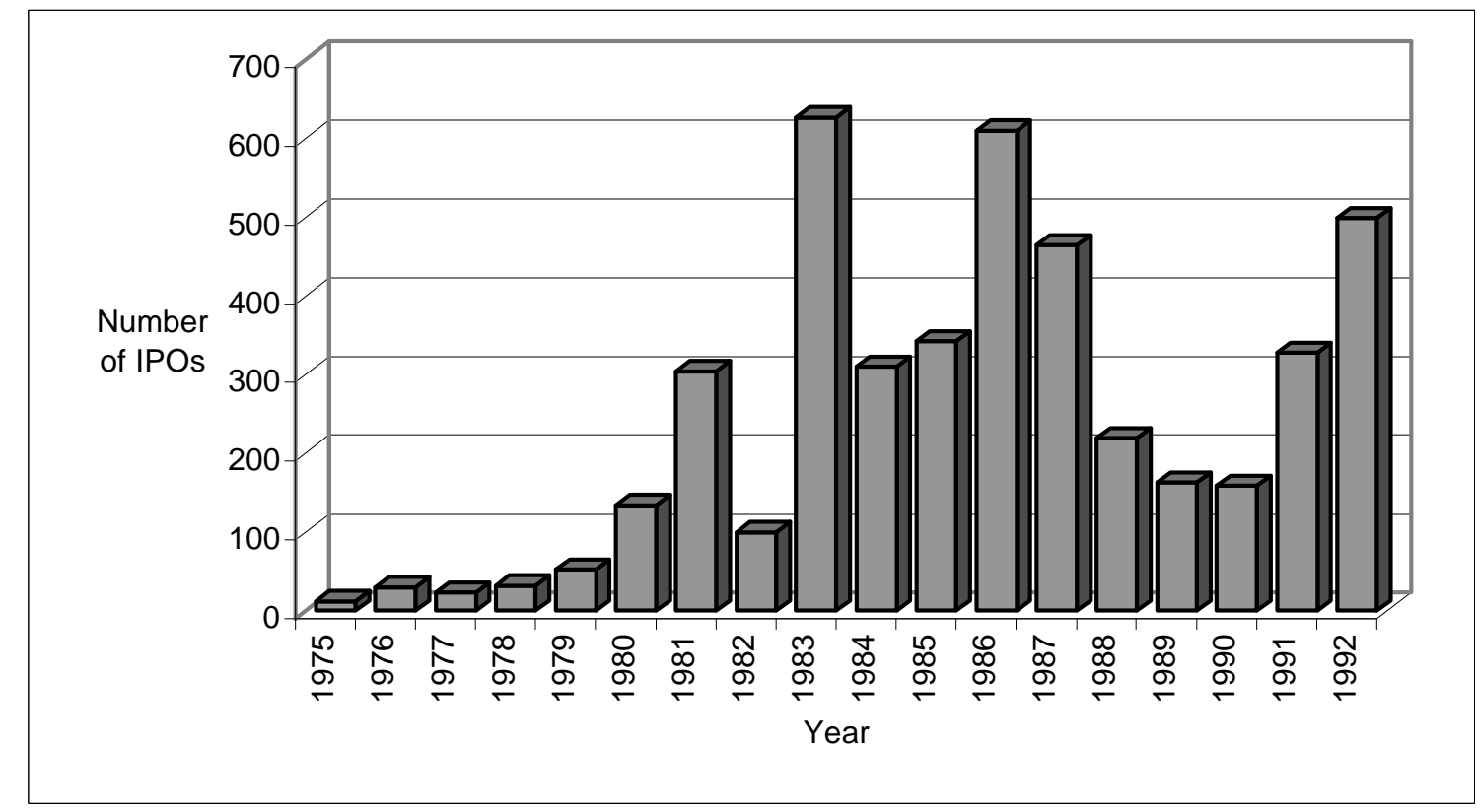

Figure 2 Time Series of Initial Public Offerings. The sample of initial public offerings is collected from various issues of the Investment Dealers' Digest of Corporate Financing for the period 1975-1995 as well as from the Securities Data Corporation database. For inclusion in the sample, a firm performing an IPO must be followed by the Center for Research in Securities Prices (CRSP) at some point after the offering date. The final sample includes 4,622 IPOs for the period 1975-1992. 


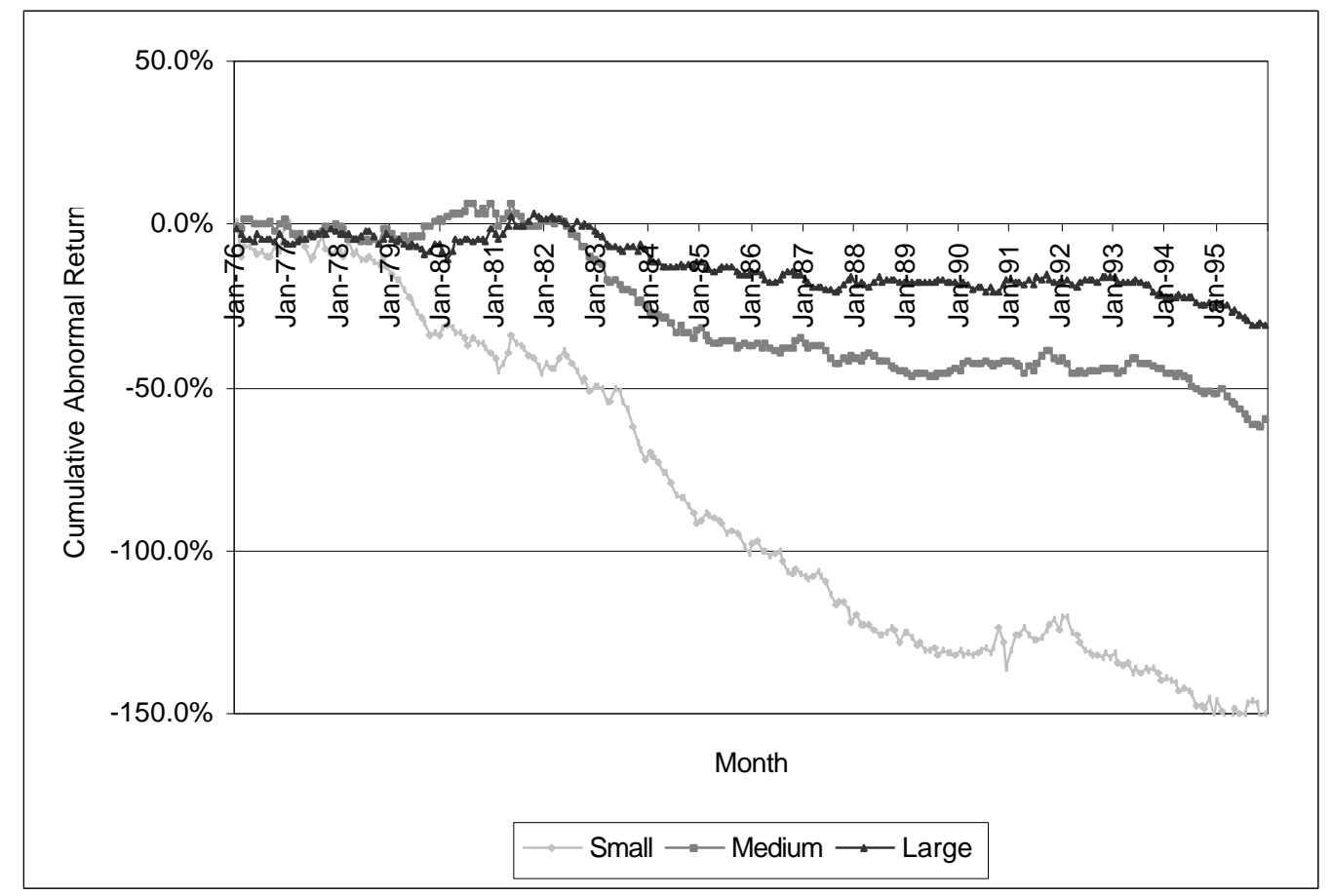

Figure 3 Calendar-time cumulative abnormal returns by size of SEO issuer. The sample is 4,526 seasoned equity offering (SEO) firms that issued equity between 1976 and 1992. For each firm in the sample we calculate a time-series regression of its excess return on the Fama and French three factors including a momentum factor where all factors have been purged of issuing firms. From each such regression we keep the intercept and residuals. We calculate size breakpoints each month using market capitalization at the beginning of the month and plot the equal weighted cumulative sum of these estimates for three size sorts. 


\section{Table 1}

The distribution of IPOs by book-to-market and size. The sample is all IPOs from 1975 through $1992 . \quad$ Size breakpoints are formed quarterly by dividing all NYSE stocks into size quintiles. Book-to-market breakpoints are formed quarterly with equal numbers of NYSE firms allocated to each of five book-to-market portfolios. The intersection of these quintile breakpoints results in 25 possible allocations.

\begin{tabular}{|c|c|c|c|c|c|c|}
\hline \multirow[b]{2}{*}{$\begin{array}{c}\text { Book-to-Market } \\
\text { Quintiles }\end{array}$} & \multicolumn{6}{|c|}{ Size Quintile } \\
\hline & Smallest & Quintile 2 & Quintile 3 & Quintile 4 & Largest & Total \\
\hline Low & $51.80 \%$ & $18.20 \%$ & $5.50 \%$ & $1.70 \%$ & $0.40 \%$ & $77.60 \%$ \\
\hline 2 & $8.20 \%$ & $1.90 \%$ & $0.90 \%$ & $0.20 \%$ & $0.10 \%$ & $11.50 \%$ \\
\hline 3 & $3.00 \%$ & $1.20 \%$ & $0.60 \%$ & $0.10 \%$ & $0.10 \%$ & $4.90 \%$ \\
\hline 4 & $1.60 \%$ & $0.60 \%$ & $0.30 \%$ & $0.10 \%$ & $0.00 \%$ & $2.60 \%$ \\
\hline High & $2.00 \%$ & $0.80 \%$ & $0.40 \%$ & $0.20 \%$ & $0.00 \%$ & $3.40 \%$ \\
\hline Total & $66.60 \%$ & $22.70 \%$ & $7.70 \%$ & $2.30 \%$ & $0.60 \%$ & $100.00 \%$ \\
\hline
\end{tabular}


Table 2

The distribution of SEOs by book-to-market and size. The sample is all SEOs from 1975 through $1992 . \quad$ Size breakpoints are formed quarterly by dividing all NYSE stocks into size quintiles. Book-to-market breakpoints are formed quarterly with equal numbers of NYSE firms allocated to each of five book-to-market portfolios. The intersection of these quintile breakpoints results in 25 possible allocations.

\begin{tabular}{c|rrrrr|r}
\hline \hline \multirow{2}{*}{$\begin{array}{c}\text { Book-to-Market } \\
\text { Quintiles }\end{array}$} & Smallest & Quintile 2 & Quintile 3 & Quintile 4 & Largest & Total \\
\hline Low & $24.10 \%$ & $12.60 \%$ & $7.30 \%$ & $4.20 \%$ & $2.40 \%$ & $50.70 \%$ \\
2 & $7.40 \%$ & $5.10 \%$ & $3.30 \%$ & $1.70 \%$ & $1.30 \%$ & $18.70 \%$ \\
3 & $4.10 \%$ & $3.20 \%$ & $2.20 \%$ & $2.30 \%$ & $1.50 \%$ & $13.20 \%$ \\
4 & $2.70 \%$ & $2.00 \%$ & $1.90 \%$ & $1.80 \%$ & $1.20 \%$ & $9.70 \%$ \\
High & $2.20 \%$ & $1.50 \%$ & $1.30 \%$ & $1.40 \%$ & $1.40 \%$ & $7.80 \%$ \\
\cline { 2 - 7 } Total & $40.50 \%$ & $24.50 \%$ & $16.00 \%$ & $11.30 \%$ & $7.80 \%$ & $100.00 \%$ \\
\hline \hline
\end{tabular}


Table 3

The long-run performance of seasoned equity offerings. The sample is 4,526 seasoned equity offerings from 1975 through 1992. Five year equal weighted and value weighted buy and hold returns on SEOs are compared with alternative benchmarks. In the first four rows we employ the S\&P 500, NASDAQ Composite, and NYSEASE-NASDAQ equal and value weight indices. Value weight results for these indices employ 4,512 observations because market capitalization in the month after the SEO for 14 firms could not be found. Value weight results are adjusted for inflation. Rows five through seven present abnormal performance measured relative to attribute-based portfolios. Size and book-to market portfolios are generated by first forming size quintile breakpoints using NYSE firms only. These quintiles are split further into book-to-market quintiles using NYSE breakpoints only. The universe of NYSE, ASE and NASDAQ firms are allocated into the resulting 25 portfolios and equal weighted monthly returns are calculated. The breakpoints for these portfolios are recalculated quarterly. Size, book-tomarket and momentum portfolios are formed as follows. We first form size quartile breakpoints using NYSE firms only and then, within each size quartile, form book-to-market quartile breakpoints using NYSE firms only. We allocate the universe of NYSE, ASE, and NASDAQ firms into these 16 portfolios and then within each portfolio form additional quartile breakpoints based on prior year returns excluding the previous month. We calculate the resulting portfolio average returns for these 64 portfolios. This portfolio formation is repeated monthly. In the first six rows we report buy and hold results while in the seventh row we report event-time rebalanced results. Buy and hold returns are generated by compounding 60 monthly returns starting in the month following the equity issue. If the SEO delists before the 60th month we compound the return up until the delisting month. Event-time rebalancing results are generated by compounding event-time monthly averages for the SEOs and their benchmark. Since some firms lack the accounting information necessary for the attribute matching we report results for 3,775 firms in rows five and six and for 4,091 in row seven. Abnormal return is the simple difference between SEO fiveyear average return and the corresponding benchmark. Wealth relatives are calculated as $\Sigma\left(1+\mathrm{R}_{\mathrm{i}, \mathrm{T}}\right) / \Sigma\left(1+\mathrm{R}_{\text {bench, } \mathrm{T}}\right.$, where $R_{i, T}$ is the holding period return on the SEO $i$ for period $T$ and $R_{\text {bench, }}$ is the return on the benchmark portfolio over the same period. All returns on the SEOs and benchmark portfolios are taken from the CRSP files.

Panel A: Buy-and-Hold Returns

\begin{tabular}{|c|c|c|c|c|c|c|c|c|}
\hline \multirow[b]{2}{*}{ Benchmarks } & \multicolumn{4}{|c|}{ Equal Weighted Buy-and-Hold Returns (\%) } & \multicolumn{4}{|c|}{ Value Weighted Buy-and-Hold Returns (\%) } \\
\hline & SEO & $\begin{array}{l}\text { Bench- } \\
\text { mark }\end{array}$ & $\begin{array}{l}\text { Abnormal } \\
\text { Return }\end{array}$ & $\begin{array}{l}\text { Wealth } \\
\text { Relative }\end{array}$ & SEO & $\begin{array}{l}\text { Bench- } \\
\text { mark }\end{array}$ & $\begin{array}{l}\text { Abnormal } \\
\text { Return }\end{array}$ & $\begin{array}{l}\text { Wealth } \\
\text { Relative }\end{array}$ \\
\hline S\&P 500 index & 57.5 & 87.6 & -30.1 & 0.84 & 75.3 & 94.3 & -19.0 & 0.90 \\
\hline NASDAQ Comp. & 57.5 & 76.9 & -19.5 & 0.89 & 75.3 & 89.5 & -14.2 & 0.93 \\
\hline CRSP VW & 57.5 & 81.5 & -24.0 & 0.87 & 75.3 & 89.5 & -14.1 & 0.93 \\
\hline CRSP EW & 57.5 & 81.6 & -24.2 & 0.87 & 75.3 & 102.2 & -26.9 & 0.87 \\
\hline $\begin{array}{l}\text { Size and Book-to- } \\
\text { Market (3,775 obs) }\end{array}$ & 57.6 & 83.9 & -26.3 & 0.86 & 72.5 & 97.5 & -25.0 & 0.87 \\
\hline $\begin{array}{l}\text { Size and Book-to- } \\
\text { Market and PR12 } \\
(3,775 \text { obs })\end{array}$ & 57.0 & 84.3 & -27.3 & 0.85 & 75.7 & 99.5 & -23.8 & 0.88 \\
\hline $\begin{array}{l}\text { Size and Book-to- } \\
\text { Market and PR12 } \\
\text { rebalanced }(4,091 \text { obs })\end{array}$ & 55.0 & 85.2 & -30.2 & 0.84 & 75.2 & 97.7 & -22.5 & 0.89 \\
\hline
\end{tabular}


Table 3 (continued)

The long-run performance of seasoned equity offerings. The sample is 4,526 seasoned equity offerings from 1975 through 1992. Five year equal weighted and value weighted buy and hold returns on SEOs are compared with alternative benchmarks. In the first four rows we employ the S\&P 500, NASDAQ Composite, and NYSEASE-NASDAQ equal and value weight indices. Value weight results for these indices employ 4,512 observations because market capitalization in the month after the SEO for 14 firms could not be found. Value weight results are adjusted for inflation. Rows five through seven present abnormal performance measured relative to attribute-based portfolios. Size and book-to market portfolios are generated by first forming size quintile breakpoints using NYSE firms only. These quintiles are split further into book-to-market quintiles using NYSE breakpoints only. The universe of NYSE, ASE and NASDAQ firms are allocated into the resulting 25 portfolios and equal weighted monthly returns are calculated. The breakpoints for these portfolios are recalculated quarterly. Size, book-tomarket and momentum portfolios are formed as follows. We first form size quartile breakpoints using NYSE firms only and then, within each size quartile, form book-to-market quartile breakpoints using NYSE firms only. We allocate the universe of NYSE, ASE, and NASDAQ firms into these 16 portfolios and then within each portfolio form additional quartile breakpoints based on prior year returns excluding the previous month. We calculate the resulting portfolio average returns for these 64 portfolios. This portfolio formation is repeated monthly. In the first six rows we report buy and hold results while in the seventh row we report event-time rebalanced results. Cumulative abnormal returns are generated by summing 60 monthly abnormal returns starting in the month following the equity issue. If the SEO delists before the 60th month we sum the return up until the delisting month. Event-time rebalancing results are generated by summing event-time monthly averages for the SEOs and their benchmark. Since some firms lack the accounting information necessary for the attribute matching we report results for 3,775 firms in rows five and six and for 4,091 in row seven. All returns on the SEOs and benchmark portfolios are taken from the CRSP files.

Panel B: Cumulative Abnormal Returns

\begin{tabular}{|c|c|c|c|c|c|c|}
\hline \multirow[b]{2}{*}{ Benchmarks } & \multicolumn{3}{|c|}{ Equal Weighted CARs (\%) } & \multicolumn{3}{|c|}{ Value Weighted CARs (\%) } \\
\hline & SEO & $\begin{array}{l}\text { Bench- } \\
\text { mark }\end{array}$ & CAR & SEO & Bench-mark & CAR \\
\hline S\&P 500 index & 51.5 & 75.5 & -24.0 & 60.4 & 70.2 & -9.8 \\
\hline NASDAQ Composite & 51.5 & 70.7 & -19.2 & 60.4 & 69.2 & -8.8 \\
\hline CRSP Value-Weighted & 51.5 & 72.0 & -20.5 & 60.4 & 68.1 & -7.8 \\
\hline CRSP Equal-Weighted & 51.5 & 68.7 & -17.15 & 60.4 & 70.4 & -10.1 \\
\hline Size and Book-to-Market (3,775 obs) & 53.2 & 68.6 & -15.4 & 56.0 & 71.9 & -15.9 \\
\hline $\begin{array}{l}\text { Size and Book-to-Market and PR12 (3,775 } \\
\text { obs) }\end{array}$ & 52.4 & 67.7 & -15.3 & 56.6 & 73.8 & -17.1 \\
\hline $\begin{array}{l}\text { Size and Book-to-Market and PR12 } \\
\text { rebalanced }(4,091 \mathrm{obs})\end{array}$ & 52.8 & 73.1 & -20.3 & 56.5 & 71.6 & -15.1 \\
\hline
\end{tabular}




\section{Table 4}

The long-run performance of initial public offerings. The sample is 4,622 initial public offerings from 1975 through 1992. Five year equal weighted and value weighted buy and hold returns on IPOs are compared with alternative benchmarks. In the first four rows we employ the S\&P 500, NASDAQ Composite, and NYSE-ASENASDAQ equal and value weight indices. Throughout, value weight results are adjusted for inflation. In row five we present abnormal performance measured relative to size and book-to market portfolios. These portfolios are generated by first forming size quintile breakpoints using NYSE firms only. These quintiles are split further into book-to-market quintiles using NYSE breakpoints only. The universe of NYSE, ASE and NASDAQ firms are allocated into the resulting 25 portfolios and we calculate equal weighted monthly returns. The breakpoints for these portfolios are recalculated quarterly. Buy and hold returns are generated by compounding 60 monthly returns starting in the month following the equity issue. Since some firms lack the accounting information necessary for the attribute matching we report results for 3,501 in row five. If the IPO delists before the 60th month we compound the return up until the delisting month. Abnormal return is the simple difference between IPO five-year average return and the corresponding benchmark. Wealth relatives are calculated as $\Sigma\left(1+\mathrm{R}_{\mathrm{i}, \mathrm{T}}\right) / \Sigma\left(1+\mathrm{R}_{\text {bench, } \mathrm{T}}\right.$, where $\mathrm{R}_{\mathrm{i}, \mathrm{T}}$ is the holding period return on the IPO $\mathrm{i}$ for period $\mathrm{T}$ and $\mathrm{R}_{\text {bench, } \mathrm{T}}$ is the return on the benchmark portfolio over the same period. All returns on the IPOs and benchmark portfolios are taken from the CRSP files.

Panel A: Buy-and-Hold Returns

\begin{tabular}{|c|c|c|c|c|c|c|c|c|}
\hline \multirow[b]{2}{*}{ Benchmarks } & \multicolumn{4}{|c|}{ Equal Weighted Buy-and-Hold Returns (\%) } & \multicolumn{4}{|c|}{ Value Weighted Buy-and-Hold Returns (\%) } \\
\hline & IPO & $\begin{array}{l}\text { Bench- } \\
\text { mark }\end{array}$ & $\begin{array}{l}\text { Abnormal } \\
\text { Return }\end{array}$ & $\begin{array}{l}\text { Wealth } \\
\text { Relative }\end{array}$ & IPO & $\begin{array}{l}\text { Bench- } \\
\text { mark }\end{array}$ & $\begin{array}{l}\text { Abnormal } \\
\text { Return }\end{array}$ & $\begin{array}{l}\text { Wealth } \\
\text { Relative }\end{array}$ \\
\hline S\&P 500 index & 33.1 & 77.3 & -44.2 & 0.75 & 52.6 & 78.3 & -25.7 & 0.86 \\
\hline NASDAQ Composite & 33.1 & 64.2 & -31.1 & 0.81 & 52.6 & 68.2 & -15.6 & 0.91 \\
\hline CRSP VW & 33.1 & 71.7 & -38.6 & 0.78 & 52.6 & 72.4 & -19.8 & 0.89 \\
\hline CRSP EW & 33.1 & 61.5 & -28.4 & 0.82 & 52.6 & 61.4 & -8.8 & 0.95 \\
\hline $\begin{array}{l}\text { Size and Book-to- } \\
\text { Market }(3,501 \text { Obs })\end{array}$ & 35.8 & 29.2 & 6.6 & 1.05 & 56.6 & 55.2 & 1.4 & 1.01 \\
\hline
\end{tabular}


Table 4 (continued)

The long-run performance of initial public offerings. The sample is 4,622 initial public offerings from 1975 through 1992. Five year equal weighted and value weighted cumulative abnormal returns on IPOs are compared with alternative benchmarks. In the first four rows we employ the S\&P 500, NASDAQ Composite and NYSEASE-NASDAQ equal and value weight indices. Throughout, value weight results are adjusted for inflation. In row five we present abnormal performance measured relative to size and book-to market portfolios. These portfolios are generated by first forming size quintile breakpoints using NYSE firms only. These quintiles are split further into book-to-market quintiles using NYSE breakpoints only. The universe of NYSE, ASE and NASDAQ firms are allocated into the resulting 25 portfolios and we calculate equal weighted monthly returns. The breakpoints for these portfolios are recalculated quarterly. Since some firms lack the accounting information necessary for the attribute matching we report results for 3,501 in row five. Cumulative abnormal returns are generated by summing 60 monthly abnormal returns starting in the month following the equity issue. If the IPO delists before the 60th month we sum up until the delisting month. All returns on the IPOs and benchmark portfolios are taken from the CRSP files.

Panel B: Cumulative Abnormal Returns

\begin{tabular}{lccc|ccc}
\hline & \multicolumn{3}{c|}{ Equal Weighted CARs (\%) } & \multicolumn{3}{c}{ Value Weighted CARs (\%) } \\
\hline Benchmarks & IPO & Bench-mark & CAR & IPO & Bench-mark & CAR \\
\hline S\&P 500 index & 35.9 & 74.2 & -38.3 & 40.7 & 61.5 & -20.8 \\
NASDAQ Composite & 35.9 & 67.9 & -32.0 & 40.7 & 57.5 & -16.8 \\
CRSP Value-Weighted & 35.9 & 70.2 & -34.3 & 40.7 & 58.1 & -17.4 \\
CRSP Equal-Weighted & 35.9 & 62.4 & -26.5 & 40.7 & 51.8 & -11.1 \\
Size and Book-to-Market (3501 Obs) & 42.3 & 32.6 & 9.7 & 53.0 & 49.7 & 3.3 \\
\hline
\end{tabular}


Table 5

Four factor regressions for twenty-five test portfolios formed on the basis of size and book-to-market. Panel A presents factor regressions for the 25 benchmark portfolios using factors formed from all CRSP-listed firms. Panel B forms the factors excluding all issuing firms, i.e., excluding all firms that issued equity in an initial public offering or seasoned equity offering during the previous five years. RMRF is the return on portfolio formed by subtracting the value weighted market return on all NYSE/ASE/NASDAQ firms (RM) minus the risk free rate (RF) which is the one-month Treasury bill rate. SMB (small minus big) is the difference each month between the return on small firms and big firms. HML (high minus low) is the difference each month between the return on a portfolio of high book-to-market stocks and the return on a portfolio of low book-to-market stocks. PR12 is the excess return on winners versus losers based on prior year returns excluding the previous month. [t-statistics are in brackets.]

Panel A: Full Sample Factors

\begin{tabular}{|c|c|c|c|c|c|}
\hline Intercept & Small & 2 & 3 & 4 & Large \\
\hline Low & $-0.0053[4.16]$ & $-0.0016[-1.90]$ & $-0.0004[-0.45]$ & 0.0013 [1.57] & $0.0013[1.52]$ \\
\hline 2 & $0.0012[1.33]$ & $0.0002[0.21]$ & $0.0007[0.90]$ & $-0.0004[-0.54]$ & $0.0009[1.01]$ \\
\hline 3 & $0.0001[0.09]$ & $0.0012[1.64]$ & $0.0000[0.02]$ & $-0.0005[-0.59]$ & $-0.0005[-0.45]$ \\
\hline High & $0.0003[0.41]$ & $-0.001[-1.20]$ & $-0.0006[-0.57]$ & $0.0004[0.33]$ & $-0.0007[-0.51]$ \\
\hline RMRF & Small & 2 & 3 & 4 & Large \\
\hline Low & 1.0498 [34.87] & $1.1060[57.12]$ & 1.0785 [54.22] & 1.0464 [52.99] & $0.9518[46.36]$ \\
\hline 2 & $1.0171[48.70]$ & $1.0506[55.73]$ & 1.0286 [52.57] & $1.0909[55.84]$ & $1.0501[49.48]$ \\
\hline 3 & $0.9599[58.57]$ & $0.9981[57.94]]$ & $0.965751 .82]$ & $1.0948[49.82]$ & $0.9790[40.79]$ \\
\hline 4 & $0.9056[52.80]$ & 0.9779 [54.41] & $0.9777[50.35]$ & $1.0528[44.48]$ & $1.0172[47.02]$ \\
\hline High & $0.9925[52.60]$ & $1.1008[57.18]$ & $1.1037[45.03]$ & $1.1686[41.20]$ & $1.0349[31.38]$ \\
\hline SMB & Small & 2 & 3 & 4 & Large \\
\hline Low & $1.3100[27.10]$ & $1.0104[32.50]$ & 0.7222 [22.62] & $0.3533[11.15]$ & $-0.1966[-5.96]$ \\
\hline 2 & $1.1893[35.47]$ & $0.9297[30.71]$ & 0.6557 [20.87] & $0.3191[10.17]$ & $-0.1690[-4.96]$ \\
\hline 4 & $1.0693[38.83]$ & $0.756126 .20]$ & $0.4651[14.91]$ & 0.1508 [3.97] & $-0.1657[-4.77]$ \\
\hline High & 1.1794 [38.93] & 0.9220 [29.83] & $0.6224[15.82]$ & $0.2816[6.18]$ & $-0.0995[-1.88]$ \\
\hline HML & Low & 2 & 3 & 4 & High \\
\hline Low & $-0.2800[-5.46]$ & $-0.5064[-15.34]$ & $-0.4221[-12.45]$ & $-0.4393[-13.05]$ & $-0.4317[-12.33]$ \\
\hline 2 & $0.0324[0.91]$ & $-0.018[-0.56]$ & $0.0418[1.25]$ & $-0.0075[-0.23]$ & $-0.0793[-2.19]$ \\
\hline 3 & $0.2237[8.00]$ & $0.2179[7.42]$ & $0.3069[9.66]$ & $0.2895[7.73]$ & $0.1444[3.53]$ \\
\hline 4 & $0.3607[12.33]$ & $0.4337[14.15]$ & 0.4214 [12.73] & $0.5133[12.72]$ & $0.482[13.07]$ \\
\hline High & $0.6500[20.21]$ & $0.6813[20.76]$ & $0.7622[18.24]$ & $0.7129[14.74]$ & 0.8193 [14.57] \\
\hline PR12 & Small & 2 & 3 & 4 & Large \\
\hline Low & $-0.0814[-1.97]$ & $-0.0033[-0.13]$ & $0.0382[1.40]$ & $-0.0045[-0.17]$ & $-0.0749[-2.66]$ \\
\hline 2 & $-0.1465[-5.12]$ & $0.0124[0.48]$ & $0.0249[0.93]$ & $-0.0384[-1.43]$ & $0.0078[0.27]$ \\
\hline 3 & $-0.046[-2.05]$ & $0.0213[0.90]$ & $0.0420[1.65]$ & $-0.0350[-1.16]$ & $0.0774[2.35]$ \\
\hline 4 & $-0.0673[-2.86]$ & $0.0494[2.00]$ & $-0.0337[-1.27]$ & $-0.0667[-2.06]$ & $-0.075-2.53]$ \\
\hline High & $-0.0574[-2.22]$ & $0.0273[1.04]$ & $0.1213[3.61]$ & $0.0205[0.53]$ & $-0.0426[-0.94]$ \\
\hline Low & 92.70 & 96.83 & 95.96 & 95.16 & 92.78 \\
\hline 2 & 95.61 & 96.04 & 94.82 & 94.58 & 92.39 \\
\hline 3 & 96.68 & 95.97 & 94.25 & 92.72 & 88.22 \\
\hline 4 & 96.00 & 95.07 & 93.24 & 89.98 & 90.03 \\
\hline High & 95.92 & 95.63 & 91.92 & 88.87 & 80.36 \\
\hline
\end{tabular}


Table 5 (continued)

Panel B: Purged Factor Regressions

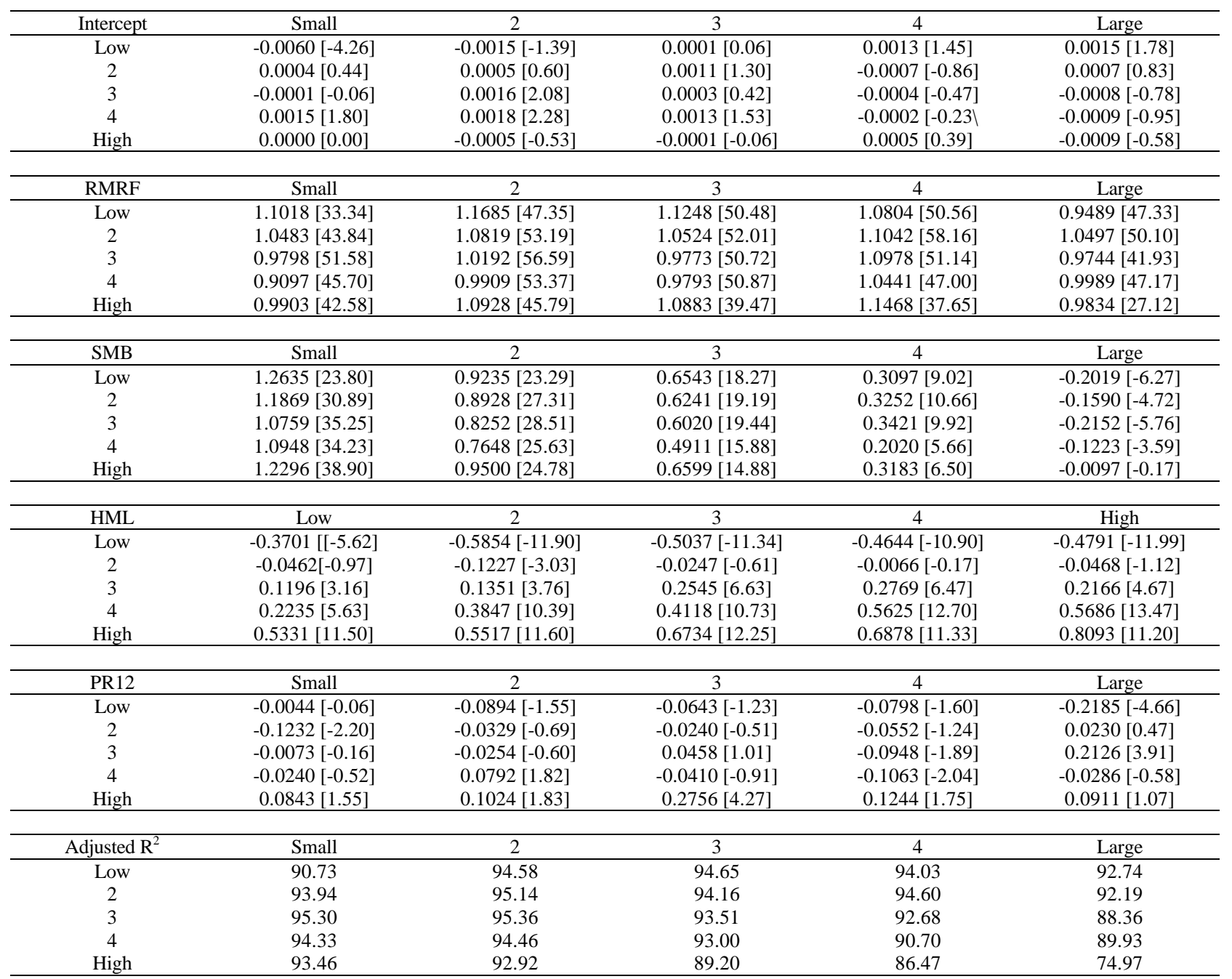


Table 6

Fama-French (1993) time-series regressions on SEO rolling portfolios for the whole sample and sorted on the basis of size. The sample of SEOs is all firms that issued equity between 1975 and 1992. Portfolios of SEOs are formed by including all issues that were done within the previous five years. RMRF is the return on portfolio formed by subtracting the value weighted market return on all NYSE/ASE/NASDAQ firms (RM) minus the risk free rate (RF) which is the one-month Treasury bill rate. SMB (small minus big) is the difference each month between the return on small firms and big firms. HML (high minus low) is the difference each month between the return on a portfolio of high book-to-market stocks and the return on a portfolio of low book-to-market stocks. PR12 is the excess return on winners versus losers based on prior year returns excluding the previous month. The first five columns presents results using the Fama and French three factor model. The next five columns add Carhart's momentum factor to the Fama and French three factors. Within each set of regressions we report equal and value weight results for the entire sample as well as equal weight results for three size sorts. [t-statistics are in brackets.]

Panel A: SEOs - Fama-French and Carhart's Factors / Size Terciles

\begin{tabular}{|c|c|c|c|c|c|c|c|c|c|c|}
\hline & \multicolumn{2}{|c|}{ Full Sample } & \multicolumn{3}{|c|}{ Size Terciles } & \multicolumn{2}{|c|}{ Full Sample } & \multicolumn{3}{|c|}{ Size Terciles } \\
\hline & $\begin{array}{c}\text { Equal } \\
\text { Weighted }\end{array}$ & $\begin{array}{l}\text { Value } \\
\text { Weighted }\end{array}$ & Small & Medium & Large & $\begin{array}{c}\text { Equal } \\
\text { Weighted }\end{array}$ & $\begin{array}{l}\text { Value } \\
\text { Weighted }\end{array}$ & Small & Medium & Large \\
\hline Intercepts & $\begin{array}{c}-0.0037 \\
{[-4.81]}\end{array}$ & $\begin{array}{c}-0.0014 \\
{[-1.36]}\end{array}$ & $\begin{array}{c}-0.0069 \\
{[-4.32]}\end{array}$ & $\begin{array}{c}-0.0026 \\
{[-3.16]}\end{array}$ & $\begin{array}{c}-0.0016 \\
{[-1.77]}\end{array}$ & $\begin{array}{r}-0.0019 \\
{[-2.56]}\end{array}$ & $\begin{array}{c}-0.0006 \\
{[-0.53]}\end{array}$ & $\begin{array}{c}-0.0026 \\
{[-1.81]}\end{array}$ & $\begin{array}{c}-0.0021 \\
{[-2.42]}\end{array}$ & $\begin{array}{c}-0.0008 \\
{[-0.85]}\end{array}$ \\
\hline RMRF & $\begin{array}{l}1.0491 \\
{[53.72]}\end{array}$ & $\begin{array}{l}0.9238 \\
{[36.10]}\end{array}$ & $\begin{array}{l}1.0693 \\
{[26.60]}\end{array}$ & $\begin{array}{c}1.0697 \\
{[50.76]}\end{array}$ & $\begin{array}{l}1.0082 \\
{[42.72]}\end{array}$ & $\begin{array}{l}1.0722 \\
{[60.87]}\end{array}$ & $\begin{array}{l}0.9340 \\
{[36.42]}\end{array}$ & $\begin{array}{l}1.1219 \\
{[31.90]}\end{array}$ & $\begin{array}{l}1.0762 \\
{[50.73]}\end{array}$ & $\begin{array}{l}1.0184 \\
{[43.16]}\end{array}$ \\
\hline SMB & $\begin{array}{l}0.7668 \\
{[25.09]}\end{array}$ & $\begin{array}{c}0.0328 \\
{[0.82]}\end{array}$ & $\begin{array}{c}1.2771 \\
{[20.30]}\end{array}$ & $\begin{array}{l}0.8292 \\
{[25.14]}\end{array}$ & $\begin{array}{c}0.1950 \\
{[5.28]}\end{array}$ & $\begin{array}{l}0.7364 \\
{[26.81]}\end{array}$ & $\begin{array}{c}0.0194 \\
{[0.49]}\end{array}$ & $\begin{array}{l}1.2078 \\
{[22.02]}\end{array}$ & $\begin{array}{l}0.8207 \\
{[24.81]}\end{array}$ & $\begin{array}{c}0.1816 \\
{[4.94]}\end{array}$ \\
\hline HML & $\begin{array}{c}-0.1021 \\
{[-3.17]}\end{array}$ & $\begin{array}{c}-0.0264 \\
{[-0.63]}\end{array}$ & $\begin{array}{l}0.0887 \\
{[1.34]}\end{array}$ & $\begin{array}{c}-0.2547 \\
{[-7.34]}\end{array}$ & $\begin{array}{c}-0.1408 \\
{[-3.62]}\end{array}$ & $\begin{array}{c}-0.1507 \\
{[-5.15]}\end{array}$ & $\begin{array}{c}-0.0478 \\
{[-1.12]}\end{array}$ & $\begin{array}{c}-0.0218 \\
{[-0.37]}\end{array}$ & $\begin{array}{c}-0.2683 \\
{[-7.61]}\end{array}$ & $\begin{array}{c}-0.1623 \\
{[-4.14]}\end{array}$ \\
\hline PR12 & & & & & & $\begin{array}{c}-0.1984 \\
{[-7.94]}\end{array}$ & $\begin{array}{c}-0.0874 \\
{[-2.40]}\end{array}$ & $\begin{array}{c}-0.4518 \\
{[-9.05]}\end{array}$ & $\begin{array}{r}-0.0557 \\
{[-1.85]}\end{array}$ & $\begin{array}{c}-0.0876 \\
{[-2.61]}\end{array}$ \\
\hline Adjusted $\mathrm{R}^{2}$ & 0.9569 & 0.8765 & 0.8695 & 0.9558 & 0.9176 & 0.9657 & 0.8789 & 0.9024 & 0.9562 & 0.9195 \\
\hline
\end{tabular}

Panel B: SEOs - Issuer Purged Factors / Size Terciles

\begin{tabular}{|c|c|c|c|c|c|c|c|c|c|c|}
\hline & \multicolumn{2}{|c|}{ Full Sample } & \multicolumn{3}{|c|}{ Size Terciles } & \multicolumn{2}{|c|}{ Full Sample } & \multicolumn{3}{|c|}{ Size Terciles } \\
\hline & $\begin{array}{c}\text { Equal } \\
\text { Weighted }\end{array}$ & $\begin{array}{l}\text { Value } \\
\text { Weighted }\end{array}$ & Small & Medium & Large & $\begin{array}{c}\text { Equal } \\
\text { Weighted }\end{array}$ & $\begin{array}{l}\text { Value } \\
\text { Weighted }\end{array}$ & Small & Medium & Large \\
\hline Intercepts & $\begin{array}{l}-0.0040 \\
{[-4.65]}\end{array}$ & $\begin{array}{c}-0.0017 \\
{[-1.63]}\end{array}$ & $\begin{array}{c}-0.0069 \\
{[-4.17]}\end{array}$ & $\begin{array}{c}-0.0030 \\
{[-3.01]}\end{array}$ & $\begin{array}{c}-0.0020 \\
{[-2.14]}\end{array}$ & $\begin{array}{c}-0.0028 \\
{[-3.34]}\end{array}$ & $\begin{array}{c}-0.0007 \\
{[-0.65]}\end{array}$ & $\begin{array}{c}-0.0050 \\
{[-3.04]}\end{array}$ & $\begin{array}{c}-0.0023 \\
{[-2.30]}\end{array}$ & $\begin{array}{c}-0.0010 \\
{[-1.04]}\end{array}$ \\
\hline RMRF & $\begin{array}{l}1.0900 \\
{[50.39]}\end{array}$ & $\begin{array}{l}0.9345 \\
{[36.74]}\end{array}$ & $\begin{array}{c}1.1157 \\
{[26.68]}\end{array}$ & $\begin{array}{l}1.1205 \\
{[44.61]}\end{array}$ & $\begin{array}{l}1.0336 \\
{[42.95]}\end{array}$ & $\begin{array}{l}1.0971 \\
{[54.03]}\end{array}$ & $\begin{array}{c}0.9402 \\
{[38.0141} \\
]\end{array}$ & $\begin{array}{l}1.1269 \\
{[28.07]}\end{array}$ & $\begin{array}{c}1.1244 \\
{[45.30]}\end{array}$ & $\begin{array}{c}1.0398 \\
{[44.83]}\end{array}$ \\
\hline SMB & $\begin{array}{l}0.7355 \\
{[20.42]}\end{array}$ & $\begin{array}{c}0.0514 \\
{[1.27]}\end{array}$ & $\begin{array}{l}1.2557 \\
{[18.92]}\end{array}$ & $\begin{array}{l}0.7667 \\
{[19.23]}\end{array}$ & $\begin{array}{l}0.1848 \\
{[4.84]}\end{array}$ & $\begin{array}{l}0.7355 \\
{[22.86]}\end{array}$ & $\begin{array}{l}0.0515 \\
{[1.31]}\end{array}$ & $\begin{array}{l}1.2558 \\
{[19.74]}\end{array}$ & $\begin{array}{l}0.7667 \\
{[19.50]}\end{array}$ & $\begin{array}{l}0.1849 \\
{[5.03]}\end{array}$ \\
\hline HML & $\begin{array}{c}-0.1183 \\
{[-2.83]}\end{array}$ & $\begin{array}{l}0.0171 \\
{[0.35]}\end{array}$ & $\begin{array}{c}-0.0064 \\
{[-0.08]}\end{array}$ & $\begin{array}{c}-0.2693 \\
{[-5.54]}\end{array}$ & $\begin{array}{l}-0.0925 \\
{[-1.99]}\end{array}$ & $\begin{array}{c}-0.1742 \\
{[-4.31]}\end{array}$ & $\begin{array}{r}-0.0283 \\
{[-0.58]}\end{array}$ & $\begin{array}{c}-0.0820 \\
{[-1.03]}\end{array}$ & $\begin{array}{c}-0.3000 \\
{[-6.07]}\end{array}$ & $\begin{array}{c}-0.1411 \\
{[-3.06]}\end{array}$ \\
\hline PR12 & & & & & & $\begin{array}{l}-0.2745 \\
{[-5.76]}\end{array}$ & $\begin{array}{r}-0.2227 \\
{[-3.84]}\end{array}$ & $\begin{array}{c}-0.4339 \\
{[-4.61]}\end{array}$ & $\begin{array}{l}-0.1506 \\
{[-2.59]}\end{array}$ & $\begin{array}{c}-0.2386 \\
{[-4.39]}\end{array}$ \\
\hline Adjusted $\mathrm{R}^{2}$ & 0.9466 & 0.8768 & 0.8574 & 0.9366 & 0.9135 & 0.9529 & 0.8835 & 0.8685 & 0.9381 & 0.9196 \\
\hline
\end{tabular}


Table 7

Fama-French (1993) time-series regressions on IPO rolling portfolios for the whole sample and sorted on the basis of size. The sample is all IPOs that issued equity between 1975 and 1992. Portfolios of IPOs are formed by including all issues that were done within the previous five years. RMRF is the return on portfolio formed by subtracting the value weighted market return on all NYSE/ASE/NASDAQ firms (RM) minus the risk free rate (RF) which is the one-month Treasury bill rate. SMB (small minus big) is the difference each month between the return on small firms and big firms. HML (high minus low) is the difference each month between the return on a portfolio of high book-to-market stocks and the return on a portfolio of low book-to-market stocks. PR12 is the excess return on winners versus losers based on prior year returns excluding the previous month. The first five columns presents results using the Fama and French three factor model. The next five columns add Carhart's momentum factor to the Fama and French three factors. Within each set of regressions we report equal and value weight results for the entire sample as well as equal weight results for three size sorts. [t-statistics are in brackets.]

Panel A: IPOs - Fama-French and Carhart's Factors / Size Terciles

\begin{tabular}{|c|c|c|c|c|c|c|c|c|c|c|}
\hline & \multicolumn{2}{|c|}{ Full Sample } & \multicolumn{3}{|c|}{ Size Terciles } & \multicolumn{2}{|c|}{ Full Sample } & \multicolumn{3}{|c|}{ Size Terciles } \\
\hline & $\begin{array}{c}\text { Equal } \\
\text { Weighted }\end{array}$ & $\begin{array}{l}\text { Value } \\
\text { Weighted }\end{array}$ & Small & Medium & Large & $\begin{array}{c}\text { Equal } \\
\text { Weighted }\end{array}$ & $\begin{array}{l}\text { Value } \\
\text { Weighted }\end{array}$ & Small & Medium & Large \\
\hline Intercepts & $\begin{array}{c}-0.0031 \\
{[-1.94]}\end{array}$ & $\begin{array}{c}-0.0011 \\
{[-0.66]}\end{array}$ & $\begin{array}{c}-0.0065 \\
{[-2.29]}\end{array}$ & $\begin{array}{c}-0.0021 \\
{[-1.15]}\end{array}$ & $\begin{array}{c}-0.0006 \\
{[-0.39]}\end{array}$ & $\begin{array}{c}-0.0009 \\
{[-0.57]}\end{array}$ & $\begin{array}{c}-0.0015 \\
{[-0.87]}\end{array}$ & $\begin{array}{c}-0.0011 \\
{[-0.39]}\end{array}$ & $\begin{array}{c}-0.0006 \\
{[-0.33]}\end{array}$ & $\begin{array}{c}-0.0010 \\
{[-0.60]}\end{array}$ \\
\hline RMRF & $\begin{array}{c}0.9798 \\
{[24.39]}\end{array}$ & $\begin{array}{l}1.0684 \\
{[25.62]}\end{array}$ & $\begin{array}{c}0.8385 \\
{[11.73]}\end{array}$ & $\begin{array}{c}1.0005 \\
{[21.31]}\end{array}$ & $\begin{array}{l}1.1013 \\
{[28.06]}\end{array}$ & $\begin{array}{c}1.0067 \\
{[25.58]}\end{array}$ & $\begin{array}{c}1.0633 \\
{[25.17]}\end{array}$ & $\begin{array}{l}0.9055 \\
{[13.40]}\end{array}$ & $\begin{array}{c}1.0189 \\
{[21.65]}\end{array}$ & $\begin{array}{l}1.0966 \\
{[27.58]}\end{array}$ \\
\hline SMB & $\begin{array}{l}1.2214 \\
{[19.42]}\end{array}$ & $\begin{array}{l}0.8459 \\
{[12.96]}\end{array}$ & $\begin{array}{l}1.4267 \\
{[12.75]}\end{array}$ & $\begin{array}{c}1.2729 \\
{[17.32]}\end{array}$ & $\begin{array}{l}0.9640 \\
{[15.69]}\end{array}$ & $\begin{array}{l}1.1860 \\
{[19.33]}\end{array}$ & $\begin{array}{l}0.8527 \\
{[12.95]}\end{array}$ & $\begin{array}{l}1.3384 \\
{[12.71]}\end{array}$ & $\begin{array}{c}1.2486 \\
{[17.02]}\end{array}$ & $\begin{array}{c}0.9702 \\
{[15.65]}\end{array}$ \\
\hline HML & $\begin{array}{c}-0.2568 \\
{[-3.88]}\end{array}$ & $\begin{array}{c}-0.5808 \\
{[-8.45]}\end{array}$ & $\begin{array}{c}0.0784 \\
{[0.67]}\end{array}$ & $\begin{array}{c}-0.2795 \\
{[-3.61]}\end{array}$ & $\begin{array}{r}-0.5637 \\
{[-8.72]}\end{array}$ & $\begin{array}{c}-0.3134 \\
{[-4.79]}\end{array}$ & $\begin{array}{l}-0.570 \\
{[-8.12]}\end{array}$ & $\begin{array}{c}-0.0624 \\
{[-0.56]}\end{array}$ & $\begin{array}{c}-0.3183 \\
{[-4.07]}\end{array}$ & $\begin{array}{c}-0.5539 \\
{[-8.38]}\end{array}$ \\
\hline PR12 & & & & & & $\begin{array}{l}-0.2310 \\
{[-4.13]}\end{array}$ & $\begin{array}{l}0.0443 \\
{[0.74]}\end{array}$ & $\begin{array}{c}-0.5752 \\
{[-6.00]}\end{array}$ & $\begin{array}{c}-0.1584 \\
{[-2.37]}\end{array}$ & $\begin{array}{c}0.0403 \\
{[0.71]}\end{array}$ \\
\hline Adjusted $\mathrm{R}^{2}$ & 0.8668 & 0.8657 & 0.6359 & 0.8353 & 0.8879 & 0.8752 & 0.8654 & 0.6822 & 0.8384 & 0.8876 \\
\hline
\end{tabular}

Panel B: IPOs - Issuer Purged Factors / Size Terciles

\begin{tabular}{|c|c|c|c|c|c|c|c|c|c|c|}
\hline & \multicolumn{2}{|c|}{ Full Sample } & \multicolumn{3}{|c|}{ Size Terciles } & \multicolumn{2}{|c|}{ Full Sample } & \multicolumn{3}{|c|}{ Size Terciles } \\
\hline & $\begin{array}{c}\text { Equal } \\
\text { Weighted }\end{array}$ & $\begin{array}{l}\text { Value } \\
\text { Weighted }\end{array}$ & Small & Medium & Large & $\begin{array}{c}\text { Equal } \\
\text { Weighted }\end{array}$ & $\begin{array}{l}\text { Value } \\
\text { Weighted }\end{array}$ & Small & Medium & Large \\
\hline Intercepts & $\begin{array}{c}-0.0030 \\
{[-1.79]}\end{array}$ & $\begin{array}{c}-0.0017 \\
{[-0.91]}\end{array}$ & $\begin{array}{c}-0.0059 \\
{[-2.05]}\end{array}$ & $\begin{array}{c}-0.0019 \\
{[-1.01]}\end{array}$ & $\begin{array}{c}-0.0011 \\
{[-0.61]}\end{array}$ & $\begin{array}{c}-0.0023 \\
{[-1.35]}\end{array}$ & $\begin{array}{c}-0.0019 \\
{[-1.03]}\end{array}$ & $\begin{array}{c}-0.0041 \\
{[-1.41]}\end{array}$ & $\begin{array}{c}-0.0016 \\
{[-0.79]}\end{array}$ & $\begin{array}{c}-0.0012 \\
{[-0.69]}\end{array}$ \\
\hline RMRF & $\begin{array}{l}1.0174 \\
{[24.13]}\end{array}$ & $\begin{array}{l}1.1295 \\
{[24.75]}\end{array}$ & $\begin{array}{l}0.8530 \\
{[11.86]}\end{array}$ & $\begin{array}{l}1.0360 \\
{[21.33]}\end{array}$ & $\begin{array}{l}1.1633 \\
{[26.59]}\end{array}$ & $\begin{array}{l}1.0212 \\
{[24.29]}\end{array}$ & $\begin{array}{l}1.1279 \\
{[24.69]}\end{array}$ & $\begin{array}{l}0.8631 \\
{[12.11]}\end{array}$ & $\begin{array}{c}1.0381 \\
{[21.36]}\end{array}$ & $\begin{array}{l}1.1624 \\
{[26.53]}\end{array}$ \\
\hline SMB & $\begin{array}{l}1.1548 \\
{[17.25]}\end{array}$ & $\begin{array}{l}0.7498 \\
{[10.35]}\end{array}$ & $\begin{array}{l}1.4044 \\
{[12.30]}\end{array}$ & $\begin{array}{l}1.2023 \\
{[15.59]}\end{array}$ & $\begin{array}{l}0.8579 \\
{[12.35]}\end{array}$ & $\begin{array}{l}1.1548 \\
{[17.33]}\end{array}$ & $\begin{array}{l}0.7498 \\
{[10.36]}\end{array}$ & $\begin{array}{l}1.4045 \\
{[12.44]}\end{array}$ & $\begin{array}{l}1.2023 \\
{[15.61]}\end{array}$ & $\begin{array}{l}0.8578 \\
{[12.35]}\end{array}$ \\
\hline HML & $\begin{array}{r}-0.4175 \\
{[-5.12]}\end{array}$ & $\begin{array}{c}-0.6010 \\
{[-6.81]}\end{array}$ & $\begin{array}{l}-0.1767 \\
{[-1.27]}\end{array}$ & $\begin{array}{c}-0.4648 \\
{[-4.95]}\end{array}$ & $\begin{array}{c}-0.6082 \\
{[-7.18]}\end{array}$ & $\begin{array}{c}-0.4472 \\
{[-5.35]}\end{array}$ & $\begin{array}{c}-0.5879 \\
{[-6.47]}\end{array}$ & $\begin{array}{c}-0.2564 \\
{[-1.81]}\end{array}$ & $\begin{array}{c}-0.4818 \\
{[-4.98]}\end{array}$ & $\begin{array}{c}-0.6006 \\
{[-6.89]}\end{array}$ \\
\hline PR12 & & & & & & $\begin{array}{c}-0.1456 \\
{[-1.48]}\end{array}$ & $\begin{array}{c}0.0642 \\
{[0.60]}\end{array}$ & $\begin{array}{c}-0.3911 \\
{[-2.34]}\end{array}$ & $\begin{array}{c}-0.0836 \\
{[-0.73]}\end{array}$ & $\begin{array}{c}0.0373 \\
{[0.36]}\end{array}$ \\
\hline Adjusted $\mathrm{R}^{2}$ & 0.8519 & 0.8377 & 0.6276 & 0.8220 & 0.8594 & 0.8526 & 0.8372 & 0.6344 & 0.8216 & 0.8588 \\
\hline
\end{tabular}


Table 8

Fama-French (1993) three factor regressions on SEO rolling portfolios for the whole sample and sorted on the basis of size for various issuances. The sample is all SEOs from 1975 through 1992. Portfolios of SEOs are formed by including all issues that were done within the previous five years. RMRF is the return on portfolio formed by subtracting the value weighted market return on all NYSE/ASE/NASDAQ firms (RM) minus the risk free rate (RF) which is the one-month Treasury bill rate. SMB (small minus big) is the difference each month between the return on small firms and big firms. HML (high minus low) is the difference each month between the return on a portfolio of high book-to-market stocks and the return on a portfolio of low book-to-market stocks. PR12 is the excess return on winners versus losers based on prior year returns excluding the previous month. The first five columns presents results using the Fama and French three factor model and Carhart's momentum to price firms conducting their first SEO in the sample period while the next five columns use the four factor model to price second or subsequent issuers. Within each set of regressions we report equal and value weight results for the entire sample as well as equal weight results for three size sorts. [t-statistics are in brackets.]

\begin{tabular}{|c|c|c|c|c|c|c|c|c|c|c|}
\hline & \multicolumn{5}{|c|}{ First Issuance } & \multicolumn{5}{|c|}{ Second or Subsequent Issuance } \\
\hline & \multicolumn{2}{|c|}{ Full Sample } & \multicolumn{3}{|c|}{ Size Terciles } & \multicolumn{2}{|c|}{ Full Sample } & \multicolumn{3}{|c|}{ Size Terciles } \\
\hline & $\begin{array}{c}\text { Equal } \\
\text { Weighted }\end{array}$ & $\begin{array}{l}\text { Value } \\
\text { Weighted }\end{array}$ & Small & Medium & Large & $\begin{array}{c}\text { Equal } \\
\text { Weighted }\end{array}$ & $\begin{array}{l}\text { Value } \\
\text { Weighted }\end{array}$ & Small & Medium & Large \\
\hline Intercepts & $\begin{array}{c}-0.0033 \\
{[-3.37]}\end{array}$ & $\begin{array}{c}-0.0012 \\
{[-1.34]}\end{array}$ & $\begin{array}{c}-0.0052 \\
{[-2.69]}\end{array}$ & $\begin{array}{c}-0.0036 \\
{[-3.01]}\end{array}$ & $\begin{array}{c}-0.0010 \\
{[-1.12]}\end{array}$ & $\begin{array}{c}-0.0012 \\
{[-1.06]}\end{array}$ & $\begin{array}{c}0.0002 \\
{[0.17]}\end{array}$ & $\begin{array}{c}-0.0030 \\
{[-1.89]}\end{array}$ & $\begin{array}{c}-0.0008 \\
{[-0.56]}\end{array}$ & $\begin{array}{l}0.0000 \\
{[-0.03]}\end{array}$ \\
\hline RMRF & $\begin{array}{l}1.1239 \\
{[47.47]}\end{array}$ & $\begin{array}{l}1.0207 \\
{[45.03]}\end{array}$ & $\begin{array}{l}1.1232 \\
{[23.77]}\end{array}$ & $\begin{array}{l}1.1458 \\
{[39.58]}\end{array}$ & $\begin{array}{r}1.1030 \\
{[48.31]}\end{array}$ & $\begin{array}{l}1.0075 \\
{[35.72]}\end{array}$ & $\begin{array}{l}0.8787 \\
{[25.30]}\end{array}$ & $\begin{array}{l}1.0829 \\
{[27.57]}\end{array}$ & $\begin{array}{l}1.0166 \\
{[29.16]}\end{array}$ & $\begin{array}{l}0.9401 \\
{[26.42]}\end{array}$ \\
\hline SMB & $\begin{array}{l}0.8623 \\
{[22.99]}\end{array}$ & $\begin{array}{c}0.1020 \\
{[2.84]}\end{array}$ & $\begin{array}{l}1.3232 \\
{[17.68]}\end{array}$ & $\begin{array}{l}0.9204 \\
{[20.06]}\end{array}$ & $\begin{array}{c}0.3448 \\
{[9.53]}\end{array}$ & $\begin{array}{l}0.4269 \\
{[9.55]}\end{array}$ & $\begin{array}{c}-0.0203 \\
{[-0.37]}\end{array}$ & $\begin{array}{l}0.9005 \\
{[14.47]}\end{array}$ & $\begin{array}{l}0.3670 \\
{[6.65]}\end{array}$ & $\begin{array}{l}0.0203 \\
{[-0.36]}\end{array}$ \\
\hline HML & $\begin{array}{l}-0.243 \\
{[-5.16]}\end{array}$ & $\begin{array}{c}-0.2013 \\
{[-4.46]}\end{array}$ & $\begin{array}{c}0.0072 \\
{[0.08]}\end{array}$ & $\begin{array}{c}-0.3757 \\
{[-6.52]}\end{array}$ & $\begin{array}{c}-0.3601 \\
{[-7.93]}\end{array}$ & $\begin{array}{c}-0.0820 \\
{[-1.46]}\end{array}$ & $\begin{array}{c}0.0615 \\
{[0.89]}\end{array}$ & $\begin{array}{r}-0.1057 \\
{[-1.35]}\end{array}$ & $\begin{array}{r}-0.0857 \\
{[-1.24]}\end{array}$ & $\begin{array}{r}-0.0237 \\
{[-0.33]}\end{array}$ \\
\hline PR12 & $\begin{array}{c}-0.2954 \\
{[-5.32]}\end{array}$ & $\begin{array}{c}-0.1961 \\
{[-3.69]}\end{array}$ & $\begin{array}{c}-0.4442 \\
{[-4.00]}\end{array}$ & $\begin{array}{l}-0.113 \\
{[-1.66]}\end{array}$ & $\begin{array}{c}-0.3287 \\
{[-6.14]}\end{array}$ & $\begin{array}{c}-0.3381 \\
{[-5.11]}\end{array}$ & $\begin{array}{c}-0.3019 \\
{[-3.71]}\end{array}$ & $\begin{array}{c}-0.4676 \\
{[-5.08]}\end{array}$ & $\begin{array}{c}-0.2793 \\
{[-3.42]}\end{array}$ & $\begin{array}{l}-0.2464 \\
{[-2.95]}\end{array}$ \\
\hline Adjusted $\mathrm{R}^{2}$ & 0.9436 & 0.9213 & 0.8271 & 0.9265 & 0.9379 & 0.8842 & 0.7585 & 0.8463 & 0.8330 & 0.7833 \\
\hline
\end{tabular}




\section{Table 9}

The long-run performance of exchange-listing changes. The sample is 1097 exchange listings from 1975 through 1992. Three-year equal weighted buy and hold (panel A) and cumulative abnormal return (panel B) on firms that change exchange listings are calculated using a size, book-to-market benchmark (see the description of formation of these portfolios in Table III.) All returns on these firms and benchmark portfolios are taken from the CRSP monthly files

Panel A: Three-Year Buy-and-Hold Abnormal Returns

\begin{tabular}{|c|c|c|c|c|c|c|c|c|}
\hline & \multicolumn{4}{|c|}{ All Exchange Listings } & \multicolumn{4}{|c|}{$\begin{array}{c}\text { Exchange Listings } \\
\text { Excluding IPO and SEO Firms }\end{array}$} \\
\hline & All Firms & $\begin{array}{l}\text { ASE to } \\
\text { NYSE }\end{array}$ & $\begin{array}{l}\text { Nasdaq to } \\
\text { ASE }\end{array}$ & $\begin{array}{l}\text { NASDAQ } \\
\text { to NYSE }\end{array}$ & All Firms & $\begin{array}{l}\text { ASE to } \\
\text { NYSE }\end{array}$ & $\begin{array}{l}\text { Nasdaq to } \\
\text { ASE }\end{array}$ & $\begin{array}{l}\text { NASDAQ } \\
\text { to NYSE }\end{array}$ \\
\hline Mean Post-Listing Return & 47.60 & 58.69 & 40.27 & 47.93 & 53.15 & 60.34 & 50.66 & 51.01 \\
\hline Mean Benchmark Return & 59.67 & 72.13 & 56.90 & 54.82 & 59.32 & 67.51 & 62.20 & 50.61 \\
\hline Mean Abnormal Return & -12.07 & -13.43 & -16.63 & -6.90 & -6.18 & -7.17 & -11.54 & 0.39 \\
\hline Median Abnormal Return & -30.46 & -19.54 & -43.90 & -24.63 & -14.79 & -6.96 & -26.55 & -11.15 \\
\hline Number & 1097 & 258 & 410 & 429 & 708 & 173 & 280 & 255 \\
\hline
\end{tabular}

Panel B: Cumulative Abnormal Returns at six-month intervals (t-statistics in brackets).

\begin{tabular}{|c|c|c|c|c|c|c|c|c|}
\hline \multirow[b]{2}{*}{$\begin{array}{l}\text { Month Since } \\
\text { Listing }\end{array}$} & \multicolumn{4}{|c|}{ All Exchange Listings } & \multicolumn{4}{|c|}{$\begin{array}{c}\text { Exchange Listings } \\
\text { Excluding IPO and SEO Firms }\end{array}$} \\
\hline & All Firms & $\begin{array}{l}\text { ASE to } \\
\text { NYSE }\end{array}$ & $\begin{array}{l}\text { Nasdaq to } \\
\text { ASE }\end{array}$ & $\begin{array}{l}\text { NASDAQ } \\
\text { to NYSE }\end{array}$ & All Firms & $\begin{array}{l}\text { ASE to } \\
\text { NYSE }\end{array}$ & $\begin{array}{l}\text { Nasdaq to } \\
\text { ASE }\end{array}$ & $\begin{array}{l}\text { NASDAQ } \\
\text { to NYSE }\end{array}$ \\
\hline \multirow[t]{2}{*}{6 months } & -1.78 & -1.99 & -2.43 & -1.04 & -1.16 & -0.55 & -2.66 & 0.14 \\
\hline & {$[-1.94]$} & {$[-1.58]$} & {$[-1.55]$} & {$[-0.71]$} & {$[-0.92]$} & {$[-0.31]$} & {$[-1.50]$} & {$[0.08]$} \\
\hline \multirow[t]{2}{*}{12 months } & -3.22 & -1.19 & -4.26 & -3.46 & -1.09 & 1.43 & -2.96 & -0.76 \\
\hline & {$[-2.48]$} & {$[-0.69]$} & {$[-1.95]$} & {$[-1.68]$} & {$[-0.60]$} & {$[0.58]$} & {$[-1.24]$} & {$[-0.32]$} \\
\hline \multirow[t]{2}{*}{18 months } & -4.94 & -2.99 & -4.71 & -6.31 & -0.85 & 2.89 & -2.00 & -2.23 \\
\hline & {$[-3.07]$} & {$[-1.41]$} & {$[-1.75]$} & {$[-2.47]$} & {$[-0.38]$} & {$[0.96]$} & {$[-0.69]$} & {$[-0.77]$} \\
\hline \multirow[t]{2}{*}{24 months } & -7.64 & -3.06 & -8.61 & -9.45 & -3.67 & 2.47 & -7.24 & -4.14 \\
\hline & {$[-4.07]$} & {$[-1.24]$} & {$[-2.76]$} & {$[-3.16]$} & {$[-1.43]$} & {$[0.71]$} & {$[-2.18]$} & {$[-1.24]$} \\
\hline \multirow[t]{2}{*}{30 months } & -9.84 & -2.41 & -12.64 & -11.69 & -4.48 & 2.65 & -8.20 & -5.46 \\
\hline & {$[-4.64]$} & {$[-0.86]$} & {$[-3.56]$} & {$[-3.47]$} & {$[-1.56]$} & {$[0.68]$} & {$[-2.20]$} & {$[-1.49]$} \\
\hline \multirow[t]{2}{*}{36 months } & -9.51 & -3.59 & -12.62 & -10.17 & -3.40 & 2.15 & -7.17 & -3.29 \\
\hline & {$[-4.03]$} & {$[-1.18]$} & {$[-3.18]$} & {$[-2.72]$} & {$[-1.10]$} & {$[0.50]$} & {$[-1.77]$} & {$[-0.84]$} \\
\hline Number & 1097 & 258 & 410 & 429 & 708 & 173 & 280 & 255 \\
\hline
\end{tabular}




\section{Table 10}

Fama-French (1993) three and four factor regressions on zero investment portfolios shorting small, growth companies and long SEO firms. Zero investment portfolios are formed by shorting the smallest and lowest book-to-market portfolio based on quintile breakpoints and going long on firms which have performed seasoned equity offerings within the past five years. RMRF is the return on portfolio formed by subtracting the value weighted market return on all NYSE/ASE/NASDAQ firms (RM) minus the risk free rate (RF) which is the one-month Treasury bill rate. SMB (small minus big) is the difference each month between the return on small firms and big firms. HML (high minus low) is the difference each month between the return on a portfolio of high book-to-market stocks and the return on a portfolio of low book-to-market stocks. PR12 is the excess return on winners versus losers based on prior year returns excluding the previous month. The first four columns present regressions using the Fama and French three factor model while the next four columns employ a four-factor model adding Carhart's momentum factor. Within each set of regressions we present results for the overall sample and three size sorts. All factors are formed deleting SEO and IPO firms within five years of equity issuance. [t-statistics are in brackets.]

\begin{tabular}{|c|c|c|c|c|c|c|c|c|}
\hline & \multirow{2}{*}{$\begin{array}{c}\text { Full } \\
\text { Sample } \\
\text { Equal } \\
\text { Weighted }\end{array}$} & \multicolumn{3}{|c|}{ Size Terciles } & \multirow{2}{*}{$\begin{array}{c}\text { Full } \\
\text { Sample } \\
\text { Equal } \\
\text { Weighted }\end{array}$} & \multicolumn{3}{|c|}{ Size Terciles } \\
\hline & & Small & Medium & Large & & Small & Medium & Large \\
\hline Intercepts & $\begin{array}{l}0.0011 \\
{[1.06]}\end{array}$ & $\begin{array}{c}-0.0018 \\
{[-1.24]}\end{array}$ & $\begin{array}{l}0.0021 \\
{[0.99]}\end{array}$ & $\begin{array}{l}0.0031 \\
{[1.27]}\end{array}$ & $\begin{array}{l}0.0020 \\
{[0.61]}\end{array}$ & $\begin{array}{c}-0.0002 \\
{[-0.17]}\end{array}$ & $\begin{array}{l}0.0024 \\
{[1.11]}\end{array}$ & $\begin{array}{l}0.0038 \\
{[1.53]}\end{array}$ \\
\hline RMRF & $\begin{array}{c}0.1134 \\
{[0.11]}\end{array}$ & $\begin{array}{l}0.1391 \\
{[3.75]}\end{array}$ & $\begin{array}{c}0.1440 \\
{[2.71]}\end{array}$ & $\begin{array}{c}0.0571 \\
{[0.94]}\end{array}$ & $\begin{array}{l}0.1185 \\
{[2.48]}\end{array}$ & $\begin{array}{l}0.1484 \\
{[4.14]}\end{array}$ & $\begin{array}{l}0.1459 \\
{[2.75]}\end{array}$ & $\begin{array}{c}0.0613 \\
{[1.01]}\end{array}$ \\
\hline SMB & $\begin{array}{c}-0.6979 \\
{[-0.70]}\end{array}$ & $\begin{array}{r}-0.1777 \\
{[-3.02]}\end{array}$ & $\begin{array}{c}-0.6666 \\
{[-7.92]}\end{array}$ & $\begin{array}{l}-1.2485 \\
{[-13.02]}\end{array}$ & $\begin{array}{l}-0.6978 \\
{[-9.67]}\end{array}$ & $\begin{array}{c}-0.1776 \\
{[-3.13]}\end{array}$ & $\begin{array}{c}-0.6666 \\
{[-7.92]}\end{array}$ & $\begin{array}{l}-1.2484 \\
{[-13.05]}\end{array}$ \\
\hline HML & $\begin{array}{c}-0.1014 \\
{[-0.10]}\end{array}$ & $\begin{array}{l}0.0233 \\
{[-0.32]}\end{array}$ & $\begin{array}{c}-0.2524 \\
{[-2.46]}\end{array}$ & $\begin{array}{c}-0.0756 \\
{[-0.65]}\end{array}$ & $\begin{array}{r}-0.1415 \\
{[-1.56]}\end{array}$ & $\begin{array}{c}-0.0493 \\
{[-0.69]}\end{array}$ & $\begin{array}{c}-0.2673 \\
{[-2.53]}\end{array}$ & $\begin{array}{c}-0.1084 \\
{[-0.90]}\end{array}$ \\
\hline PR12 & & & & & $\begin{array}{c}-0.1972 \\
{[-1.85]}\end{array}$ & $\begin{array}{c}-0.3566 \\
{[-4.24]}\end{array}$ & $\begin{array}{c}-0.0733 \\
{[-0.59]}\end{array}$ & $\begin{array}{l}-0.1613 \\
{[-1.14]}\end{array}$ \\
\hline Adjusted R2 & 0.2781 & 0.0732 & 0.2334 & 0.4082 & 0.2852 & 0.1344 & 0.2312 & 0.4089 \\
\hline
\end{tabular}

